\title{
Microstructure and Mechanical Properties of Mg-RE-TM Cast Alloys Containing Long Period Stacking Ordered Phases: A Review
}

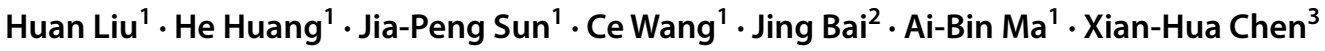 \\ Received: 30 September 2018 / Revised: 15 November 2018 / Published online: 6 December 2018 \\ (c) The Chinese Society for Metals (CSM) and Springer-Verlag GmbH Germany, part of Springer Nature 2018
}

\begin{abstract}
Casting magnesium alloys hold the greatest share of magnesium application products due to their short processing period, low cost and near net shape forming. Compared with conventional commercial magnesium alloys or other Mg-RE-based alloys, the novel Mg-RE-TM cast alloys with long period stacking ordered (LPSO) phases usually possess a higher strength and are promising candidates for aluminum alloy applications. Up to now, two ways: alloying design and casting process control (including subsequent heat treatments), have been predominantly employed to further improve the mechanical properties of these alloys. Alloying with other elements or ceramic particles could alter the solidification pattern of alloys, change the morphology of LPSO phases and refine the microstructures. Different casting techniques (conventional casting, rapidly solidification, directional solidification, etc.) introduce various microstructure characteristics, such as dendritic structure, nanocrystalline, metastable phase, anisotropy. Further heat treatments could activate the transformation of various LPSO structures and precipitation of diverse precipitates. All these evolutions exert great impacts on the mechanical properties of the LPSO-containing alloys. However, the underlying mechanisms still remain a subject of debate. Therefore, this review mainly provides the state of the art of the casting magnesium alloys research and the accompanying challenges and summarizes some topics that merit future investigation for developing high-performance $\mathrm{Mg}-\mathrm{RE}-\mathrm{TM}$ cast alloys.
\end{abstract}

Keywords Magnesium alloys $\cdot$ Long period stacking ordered phase $\cdot$ Casting $\cdot$ Heat treatment $\cdot$ Phase transformations $\cdot$ Mechanical properties

\section{Introduction}

Owing to the obvious beneficial effects of rare-earth (RE) elements on Mg alloys, Mg-RE alloy system usually displays higher strength, better ductility and superior heat resistance than those RE-free magnesium alloys, thereby holding great promise for applications in aerospace, military

Available online at http://link.springer.com/journal/40195

Huan Liu

liuhuanseu@hhu.edu.cn

Xian-Hua Chen

xhchen@cqu.edu.cn

1 College of Mechanics and Materials, Hohai University, Nanjing 211100, China

2 College of Materials Science and Engineering, Southeast University, Nanjing 211189, China

3 National Engineering Research Center for Magnesium Alloys (CCMg), Chongqing University, Chongqing 400044, China and transportation [1]. Among various $\mathrm{Mg}-\mathrm{RE}$ alloy series, Mg-RE-TM (transition metal) alloys containing long period stacking ordered (LPSO) phases have received much attention in the last decade because of their extraordinary mechanical properties [2]. LPSO structure was first identified in a $\mathrm{Mg}-\mathrm{Y}-\mathrm{Zn}-\mathrm{Zr}$ alloy by Luo et al. $[3,4]$ in the last century. Afterward, Kawamura et al. [5] developed an LPSO-containing $\mathrm{Mg}_{97} \mathrm{Y}_{2} \mathrm{Zn}_{1}$ (at.\%) alloy using rapidly solidified powder metallurgy (RS/PM) method, which exhibited an ultra-high tensile yield strength of $610 \mathrm{MPa}$ and a moderate elongation of $5 \%$. This important discovery provided a brand new insight for strengthening and toughening of novel magnesium alloys. Since then, great efforts have been made to develop high-performance LPSO-containing $\mathrm{Mg}$ alloys, and these investigations were mainly concentrated on two aspects: the alloying design and the processing control [6-66].

LPSO phase has been observed in abundant Mg-RE-TM alloys, where RE elements could be Y, Gd, Tb, Dy, Ho, $\mathrm{Er}$, Tm [6], and TM elements mainly include $\mathrm{Zn}, \mathrm{Cu}, \mathrm{Ni}$, 
Co and Al [7-14]. For different alloy systems, the structure of generated LPSO is diverse. For example, 18R and $14 \mathrm{H}$ LPSO structures are the most commonly observed and could form in almost all Mg-RE-TM alloys [15]. 10H and 24R LPSO structures were only reported in $\mathrm{Mg}-\mathrm{Y}-\mathrm{Zn}$ series [16-18]. Three novel LPSO phases with 15R, 12H and 21R structures were discovered in an $\mathrm{Mg}-\mathrm{Co}-\mathrm{Y}$ alloy [13]. More recently, Li et al. [19] observed an 12R LPSO structure in $\mathrm{Mg}_{80} \mathrm{Ni}_{5} \mathrm{Y}_{15}$ alloy. Based on the high-angle annular dark field scanning transmission electron microscopy (HAADFSTEM) analysis, all LPSO structures consist of two or three A $B C$ A-type building blocks with 1-4 $\alpha-\mathrm{Mg}$ layers inserted between, and the combination mode of the building blocks and the number of $\alpha-\mathrm{Mg}$ layers determine the types of LPSO phases [20]. Moreover, the contributions of various LPSO phases to the mechanical properties of magnesium alloys are also varied [21]. In general, 18R and 14H LPSO phases play a more important role in strengthening magnesium alloys than other types of LPSO phases, as $18 \mathrm{R}$ and $14 \mathrm{H}$ phases are more stable and they could be precipitated principally in the alloy, while the rest are rarely observed in large quantities [18].

$\mathrm{Mg}-\mathrm{Y}-\mathrm{Zn}$ and $\mathrm{Mg}-\mathrm{Gd}-\mathrm{Zn}$ alloys garnered the most extensive attention due to their relative lower cost and superior properties [22-28]. With the change of $\mathrm{Y} / \mathrm{Zn}$ mole ratio in $\mathrm{Mg}-\mathrm{Y}-\mathrm{Zn}$ alloys, three ternary phases could be formed in sequence, namely, LPSO phase $\left(\mathrm{Mg}_{12} \mathrm{YZn}\right), \mathrm{W}$-phase $\left(\mathrm{Mg}_{3} \mathrm{Y}_{2} \mathrm{Zn}_{3}\right)$ and I-phase $\left(\mathrm{Mg}_{3} \mathrm{YZn}_{6}\right)$ [22-26]. In general, LPSO phase exhibits the most strengthening effect and the $\alpha-\mathrm{Mg} / \mathrm{LPSO}$ double-phase alloys are obtained when the $\mathrm{Y} / \mathrm{Zn}$ mole ratio is near $2[23,25]$. As for the $\mathrm{Mg}-\mathrm{Gd}-\mathrm{Zn}$ alloys, $\mathrm{Mg}_{3} \mathrm{Gd}$ and $\mathrm{Mg}_{5} \mathrm{Gd}$ phases usually form apart from the LPSO phase [27, 28]. Moreover, to obtain a superior mechanical property, some quarternary or multicomponent alloys have also been developed, such as $\mathrm{Mg}-\mathrm{Gd}-\mathrm{Y}-\mathrm{Zn}$ [29-31], Mg-Gd-Er-Zn [32, 33], Mg-Gd-Dy-Zn [34], and so on $[35,36]$.

Although alloying design is important for these LPSOcontaining alloys, the processing techniques determine the mechanical properties of $\mathrm{Mg}-\mathrm{RE}-\mathrm{Zn}$ alloys by tailoring the types, distributions and morphologies of LPSO structures [37-66]. It has been widely accepted that plastic processing could significantly improve the strength of LPSO-containing alloys $[37,38]$. However, most of the magnesium alloy products nowadays are casting alloys due to their short processing period, low cost and near net shape forming [67]. Therefore, the LPSO-containing cast alloys hold greater application potential than their wrought counterparts. As a result of the synergistic strengthening effects of solid solution strengthening, fine-grained strengthening, second-phase strengthening and precipitation strengthening, $\mathrm{Mg}-\mathrm{RE}-\mathrm{Zn}$ alloys with LPSO phase exhibit superior mechanical properties at room and elevated temperatures than commercial casting magnesium alloys. So far, various processing techniques, such as rapidly solidification [5, 39-45], directional solidification [46-53], solid solution treatment [54-57], aging [21, 32, 33, 58-60], and so on [61-66], have already been performed on LPSO-containing cast alloys to tailor their microstructures and properties. To further provide a guidance on the development of high-performance LPSOcontaining $\mathrm{Mg}-\mathrm{RE}-\mathrm{Zn}$ cast alloys with low cost and broad applications, it is imperative to understand the relationships of microstructural evolutions, processing methods and mechanical behaviors. In this review, therefore, we mainly focus on the effect of different casting technologies and heat treatments on the types, morphologies and distributions of LPSO phases, as well as their influences on the mechanical properties of the alloys.

\section{Conventional Casting}

\subsection{LPSO Morphologies in Cast Alloys}

$\mathrm{Mg}-\mathrm{RE}-\mathrm{Zn}$ cast alloys were mostly prepared via induction melting or resistance heating methods, and gravity casting in metal (steel or copper) molds [8, 23, 68]. Based on the microstructure of cast alloys, the LPSO-containing $\mathrm{Mg}-\mathrm{RE}-\mathrm{Zn}$ alloys could be classified into two types. Type-I includes $\mathrm{Mg}-\mathrm{Y}-\mathrm{Zn}, \mathrm{Mg}-\mathrm{Dy}-\mathrm{Zn}, \mathrm{Mg}-\mathrm{Ho}-\mathrm{Zn}$, $\mathrm{Mg}-\mathrm{Er}-\mathrm{Zn}$ and $\mathrm{Mg}-\mathrm{Tm}-\mathrm{Zn}$ alloy series, where $18 \mathrm{R}$ LPSO phase forms during solidification $[6,15]$. Type-II mainly contains $\mathrm{Mg}-\mathrm{Gd}-\mathrm{Zn}$ and $\mathrm{Mg}-\mathrm{Tb}-\mathrm{Zn}$ alloys, where LPSO phase is initially absent in the cast microstructure but forms and propagates within $\alpha-\mathrm{Mg}$ grains during subsequent heat treatments [6].

The morphology and distribution of LPSO phase in cast $\mathrm{Mg}-\mathrm{Y}-\mathrm{Zn}$ alloys are dependent on the $\mathrm{Y} / \mathrm{Zn}$ atomic ratio and total amount of $Y$ and $Z n$ elements [23, 24, 69]. $\mathrm{Mg}-\mathrm{Y}-\mathrm{Zn}$ alloys with a $\mathrm{Y} / \mathrm{Zn}$ atomic ratio of around 2 were favored in most researches, as LPSO phase serves as the only second phase in the microstructure [70-72]. Moreover, the volume fraction and morphology of LPSO phase change dramatically with the variation in the $\mathrm{Y}$ and $\mathrm{Zn}$ contents. Figure 1 shows the SEM images of $\mathrm{Mg}-\mathrm{Y}-\mathrm{Zn}$ cast alloys with a constant $\mathrm{Y} / \mathrm{Zn}$ atomic ratio of around 2 and with different contents of solute elements [70, 72]. As the solute atoms increase, the volume fraction of $18 \mathrm{R}$ LPSO phase increases from 3.6 to $54 \%$ gradually. In the case of low concentrations of $\mathrm{Y}$ and $\mathrm{Zn}$ elements, the LPSO particles display an isolated island shape (Fig. 1a). Then, a semi-continuous network (Fig. 1b) and a three-dimensional continuous network (Fig. 1c, d) form at grain boundaries with the increase in solute atoms. In addition, Fig. 1 shows that 18R LPSO blocks present the same crystallographic orientation in each individual grain and diverse orientations across different 

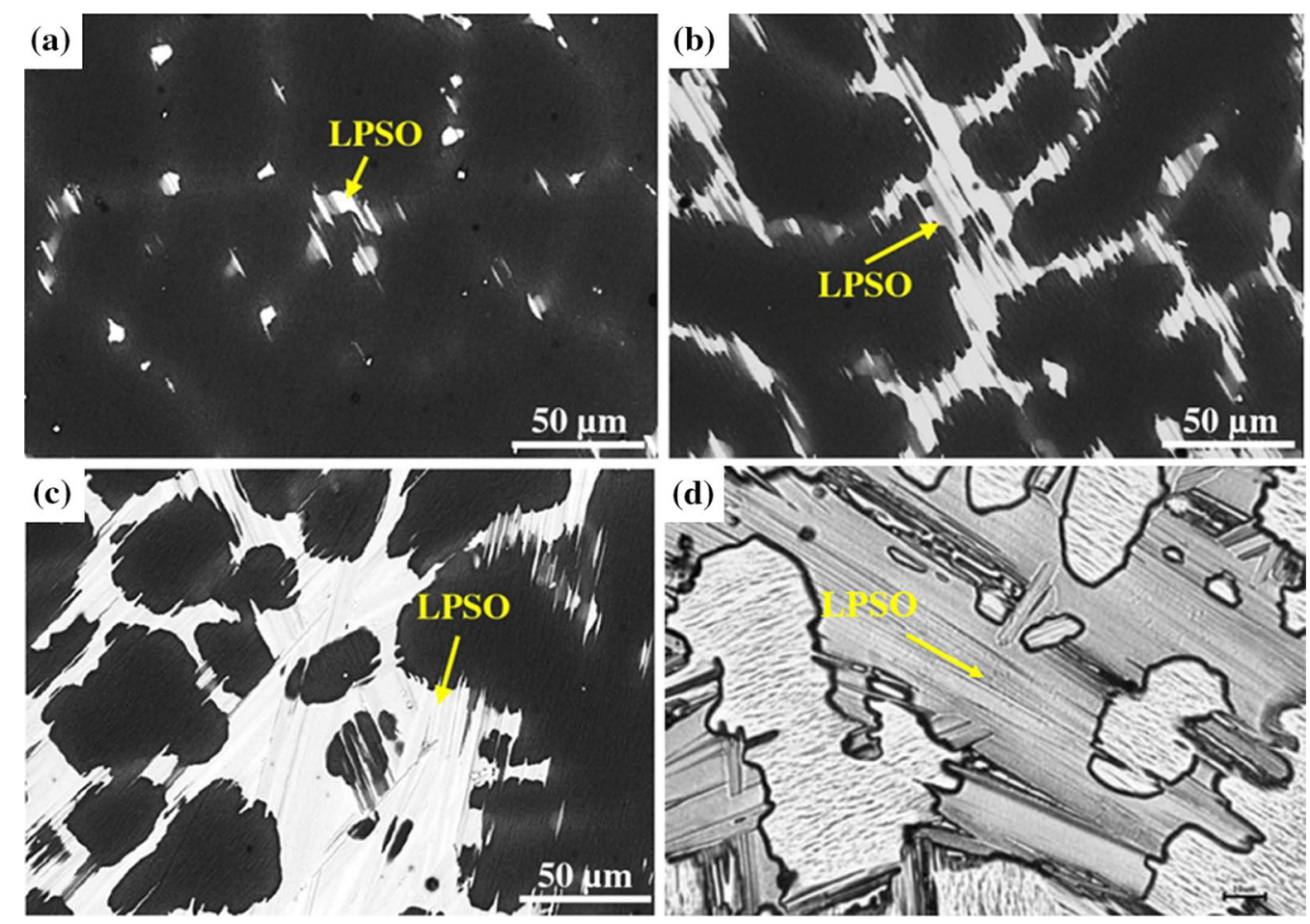

Fig. 1 Microstructure of a $\mathrm{Mg}_{99.21} \mathrm{Y}_{0.45} \mathrm{Zn}_{0.34}, \mathbf{b} \mathrm{Mg}_{97.7} \mathrm{Y}_{1.5} \mathrm{Zn}_{0.8}, \mathbf{c} \mathrm{Mg}_{96.5} \mathrm{Y}_{2.3} \mathrm{Zn}_{1.2}, \mathbf{d ~ M g} \mathrm{Mg}_{94} \mathrm{Y}_{4} \mathrm{Zn}_{2}$ alloys: a-c backscattered electron images [70]; d secondary electron image [72]

grains, resulting from the special orientation relationships between LPSO phase and $\alpha-M g$ grains $[18,20]$. Apart from $\mathrm{Mg}-\mathrm{Y}-\mathrm{Zn}$ alloys, $\mathrm{Mg}-\mathrm{Dy}-\mathrm{Zn}$ and $\mathrm{Mg}-\mathrm{Er}-\mathrm{Zn}$ alloys garnered the most attention from an economic standpoint. The relevant research results showed that the morphology and evolution of LPSO phase in these alloys were identical to those in $\mathrm{Mg}-\mathrm{Y}-\mathrm{Zn}$ alloys [6, 55, 60].

For the $\mathrm{Mg}-\mathrm{Gd}-\mathrm{Zn}$ alloy system, the situation becomes more complicated. It used to be classified into type-II as no LPSO phase was observed in its cast microstructure [6]. However, in 2009, Wu et al. [73] first reported that fine lamellae with $14 \mathrm{H}$ LPSO structure were observed within $\alpha$-Mg grains of as-cast $\mathrm{Mg}_{96.82} \mathrm{Gd}_{2} \mathrm{Zn}_{1} \mathrm{Zr}_{0.18}$ alloy and therefore suggested that $\mathrm{Mg}-\mathrm{Gd}-\mathrm{Zn}$ alloy should be included in type-I. The 14H LPSO phase exhibits thin lamellar shape, extending from grain boundaries into grain interior. Similar to $18 \mathrm{R}$ phase, the $14 \mathrm{H}$ lamellae are parallel with each other within one grain and exhibit diverse directions for different grains, owing to the specific orientation relationships between LPSO phase and $\alpha-\mathrm{Mg}$ matrix $[73,74]$. More recently, Wu et al. [75] also found the existence of 18R lamellae at grain boundaries of as-cast $\mathrm{Mg}_{96} \mathrm{Gd}_{3} \mathrm{Zn}_{1}$ alloy, with the coexistence of $14 \mathrm{H}$ fine lamellae within $\alpha-\mathrm{Mg}$ matrix. This was the first report that $18 \mathrm{R}$ and $14 \mathrm{H}$ appeared simultaneously in the as-cast $\mathrm{Mg}-\mathrm{Gd}-\mathrm{Zn}$ alloy. It is known that the difference between 18R and 14H LPSO and other LPSO structures is the arrangement of $A \boldsymbol{B C} A$ building units.
Zhu et al. [18] observed the existence of $18 \mathrm{R}, 14 \mathrm{H}$ and $24 \mathrm{R}$ LPSO fragments by HAADF-TEM in the same $\mathrm{Mg}-\mathrm{Y}-\mathrm{Zn}$ sample and speculated that solidification conditions could disturb the formation process of LPSO phase and result in diverse LPSO structures. Although this has only been demonstrated in the $\mathrm{Mg}-\mathrm{Y}-\mathrm{Zn}$ alloys for now, the same is highly like true for the $\mathrm{Mg}-\mathrm{Gd}-\mathrm{Zn}$ alloys.

\subsection{Relationship Between Microstructure and Cooling Rate}

The formation of LPSO phase involves the generation of orderly arranged stacking faults and diffusion of RE and $\mathrm{Zn}$ atoms into the SFs $[18,40]$. Two factors could affect the formation process of LPSO phase: alloy compositions and solidification conditions. Apart from various solidification techniques, cooling rate plays a crucial role in determining the morphology of LPSO phase in cast Mg-RE-TM alloys.

Generally, cooling rate influences the formation process of LPSO phase mainly by affecting the diffusion rate of solute atoms. The slower the cooling rate, the more sufficient time for diffusion of RE and $\mathrm{Zn}$ atoms, and therefore the larger of LPSO phase. Yamasaki et al. [76] prepared four $\mathrm{Mg}_{97} \mathrm{Y}_{2} \mathrm{Zn}_{1}$ alloys via high-frequency induction melting and gravity casting in steel mold by controlling the cooling rates at $0.06{ }^{\circ} \mathrm{C} / \mathrm{s}, 0.18{ }^{\circ} \mathrm{C} / \mathrm{s}, 5.7^{\circ} \mathrm{C} / \mathrm{s}$ and $9.6^{\circ} \mathrm{C} / \mathrm{s}$, respectively. They found that the average grain size of $\mathrm{Mg}_{97} \mathrm{Y}_{2} \mathrm{Zn}_{1}$ alloy 
decreased from 0.91 to $0.41 \mathrm{~mm}$ with increasing cooling rate, and the secondary dendrite arm spacing (SDAS) also declined following an empirical relationship (Eq. 1) between SDAS and cooling rate:

$d=A \cdot R_{\mathrm{c}}^{B}$,

where $d$ is SDAS; $R_{\mathrm{c}}$ is cooling rate; $A$ and $B$ are constants for a given alloy system; and they are 37.1 and -0.33 , respectively, for $\mathrm{Mg}_{97} \mathrm{Y}_{2} \mathrm{Zn}_{1}$ alloy. Increasing cooling rate resulted in the refinement of the dendritic $\alpha$-Mg grains, thus improving the dispersion of the LPSO phase in the cast state. However, it is interesting to notice that the volume fractions of the 18R LPSO phase in four $\mathrm{Mg}_{97} \mathrm{Y}_{2} \mathrm{Zn}_{1}$ alloys were all about $24 \%$ regardless of the cooling rate. This might be ascribed to the specific alloy composition which intrinsically determines the microstructure constitutes of $\alpha-\mathrm{Mg}$ and $18 \mathrm{R}$ LPSO phase.

However, for a more complex alloy system, the distribution and morphology of LPSO phase with various cooling rates could become a little more sophisticated. Zhang et al. [77] studied the microstructure of a $\mathrm{Mg}-10 \mathrm{Gd}-3 \mathrm{Y}-1.8 \mathrm{Zn}-0.5 \mathrm{Zr}$ alloy at various cooling rates from $10^{4}$ to $0.005^{\circ} \mathrm{C} / \mathrm{s}$. They found that no LPSO phase formed at a high cooling rate of $10^{4}{ }^{\circ} \mathrm{C} / \mathrm{s}$. With the decrease in cooling rate from 5 to $0.1{ }^{\circ} \mathrm{C} / \mathrm{s}$, two types of $14 \mathrm{H}$ LPSO phases were generated gradually: $14 \mathrm{H}$ LPSO blocks at grain boundaries and fine $14 \mathrm{H}$ lamellae spreading from boundaries to grain interior. For the alloys solidified at the slowest cooling rate of $0.005{ }^{\circ} \mathrm{C} / \mathrm{s}$, lamellar $14 \mathrm{H}$-LPSO structure penetrated throughout the whole matrix grain. Therefore, it can be concluded that the lamellar 14H LPSO phase might be the equilibrium phase for these alloys, and the low cooling rate provides sufficient time for the nucleation and flourishing growth of $14 \mathrm{H}$ lamellae.

\subsection{Effect of Alloying Element on Microstructure}

Apart from the LPSO-forming elements, such as RE, $\mathrm{Cu}$ and $\mathrm{Ni}$, other elements were also added into $\mathrm{Mg}-\mathrm{RE}-\mathrm{Zn}$ alloys in order to tailor their microstructure and mechanical properties. By far, the reported alloying elements in $\mathrm{Mg}-\mathrm{RE}-\mathrm{Zn}$ alloys include $\mathrm{Zr}$ [78, 79], $\mathrm{Sr}$ [80], Ca [81, 82], B [68], Ti [83], Sn [84] and Mn [85] elements. More recently, the $\mathrm{B}_{4} \mathrm{C}$ and $\mathrm{TiB}_{2}$ particles were even introduced in the LPSOcontaining alloys $[86,87]$. Among these elements, $\mathrm{Zr}$ is the most commonly added element, especially for $\mathrm{Mg}-\mathrm{Y}-\mathrm{Zn}$, $\mathrm{Mg}-\mathrm{Gd}-\mathrm{Zn}$ and $\mathrm{Mg}-\mathrm{Gd}-\mathrm{Y}-\mathrm{Zn}$ alloy systems. It was found that 0.2 at.\% $\mathrm{Zr}$ addition in $\mathrm{Mg}_{96} \mathrm{Gd}_{3} \mathrm{Zn}_{1}$ alloy could not only refine the grain size by providing nucleation sites for $\alpha-M g$ phase, but also cause the transformation of the eutectic structure from dendrite shape to homogeneous spherical shape [78]. Moreover, the content of $\mathrm{Zr}$ also affected the refining effect. Zhang et al. [79] reported that the refining effect of $\mathrm{Mg}_{94-x} \mathrm{Zn}_{1.5} \mathrm{Dy}_{4.5} \mathrm{Zr}_{x}$ was obvious when the $\mathrm{Zr}$ content was lower than 0.17 at.\%, but attenuated with further increasing the $\mathrm{Zr}$ content to 0.35 at.\%. Similar to the $\mathrm{Zr}$ element, the addition of $\mathrm{Sr}, \mathrm{Ca}, \mathrm{Mn}, \mathrm{B}$ and Ti elements also yielded significant refining effects on the $\mathrm{Mg}-\mathrm{RE}-\mathrm{Zn}$ alloys, and their additions have critical values. For example, the addition of 0.34 at.\% Ca delivered the most effective refining effect on the $\mathrm{Mg}_{94-x} \mathrm{Zn}_{2.5} \mathrm{Y}_{2.5} \mathrm{Mn}_{1} \mathrm{Ca}_{x}$ alloy when compared with other additive amounts from 0 to 0.67 at.\% [81].

Moreover, the introduction of various alloying elements could influence the morphology of LPSO phases. For instance, adding 0.04 at.\% Sr promoted the precipitation of LPSO phase during solidification [80]. Compared with $\mathrm{Mg}_{94} \mathrm{Zn}_{2} \mathrm{Y}_{4}$ alloy, the LPSO phase was thinner in the Sr-containing alloy, and its volume fraction was much higher. The incorporation of $\mathrm{Ca}$ element also stimulated the formation of LPSO phase and delayed the generation of $\mathrm{Mg}_{3} \mathrm{Y}_{2} \mathrm{Zn}_{3}$ phase [81]. Therefore, even in the $\mathrm{Mg}-\mathrm{Zn}-\mathrm{Y}-\mathrm{Mn}$ alloy with a low $\mathrm{Y} / \mathrm{Zn}$ atomic ratio, the volume fraction of LPSO phase was greatly increased by adding moderate calcium. Similar phenomenon was also confirmed by $B$ addition [68]. Importing a small amount of $\mathrm{B}$ to the as-cast $\mathrm{Mg}_{94} \mathrm{Zn}_{2.5} \mathrm{Y}_{2.5} \mathrm{Mn}_{1}$ alloy could significantly increase the volume fraction of LPSO phase from $5.8 \%$ at $0 \mathrm{wt} \% \mathrm{~B}$ to $21.9 \%$ at $0.003 \mathrm{wt} \% \mathrm{~B}$. Zhang et al. $[68,81]$ contributed the increase in LPSO phase to the lowered stacking faults energy (SFE) by adding various alloying elements that have large differences with $\mathrm{Mg}$ in atomic radius. As for the $\mathrm{Zr}$ element, however, its increase could suppress the formation of LPSO phases in the as-cast $\mathrm{Mg}_{94-x} \mathrm{Zn}_{1.5} \mathrm{Dy}_{4.5} \mathrm{Zr}_{x}$ alloy, and $\mathrm{Mg}_{8} \mathrm{ZnDy}$ eutectic phases, rather than LPSO phase, were observed with 0.35 at.\% addition in this alloy [79].

To further decrease the cost of Mg-RE-Zn alloys, misch metal was also selected to substitute the expensive RE elements. Zhang et al. [88] found that the grain size decreased gradually with increasing Yttrium-rich misch metal (Ymm), and the morphology of second phase changed from semicontinuous network to continuous network. Unlike the $\mathrm{Mg}-\mathrm{Y}-\mathrm{Zn}$ alloys, the as-cast $\mathrm{Mg}-\mathrm{Ymm}-\mathrm{Zn}$ alloys possessed both 18R and 14H LPSO phases by water-cooled mold casting, suggesting that the solidification behavior of the alloy was changed by the substitution of Ymm.

\section{Heat Treatments of Solidified Alloys}

Various heat treatments have been conducted on the LPSOcontaining $\mathrm{Mg}-\mathrm{RE}-\mathrm{Zn}$ alloys in order to tune their microstructures and improve their mechanical properties. Based on the different objectives, the heat treatments could be simply divided into two types. The first type is high-temperature annealing or solution treatment, which could tailor the types, volume fractions and distributions of various LPSO phases 
(18R and $14 \mathrm{H}$ mainly) by changing the annealing parameters [54-57]. The second type is aging [21, 32, 33, 58-60]. As the solubility limits of RE elements in magnesium usually exhibit a sharp decrease with decreasing temperature, age hardening by precipitates is a prominent feature for $\mathrm{Mg}-\mathrm{RE}-$ based alloys.

\subsection{Annealing or Solution Treatment}

\subsubsection{Microstructure Evolution}

For both type-I and type-II Mg-RE-Zn alloys, a new kind of $14 \mathrm{H}$ LPSO phase is formed when annealed at higher temperatures above $350{ }^{\circ} \mathrm{C}[8,89,90]$. Usually, this $14 \mathrm{H}$ phase exhibits a lamellar or needle-like shape, spreading from grain boundaries to grain interior with the same direction in a grain. Moreover, as for the type-I alloys, such as the $\mathrm{Mg}-\mathrm{Y}-\mathrm{Zn}$ alloy, the network-shaped 18R LPSO phase that formed in the cast stage will be gradually vanished (or transformed to $14 \mathrm{H}$ ) during annealing [91]. A wide range of factors, such as the annealing temperature and time, cooling mode and cooling rate after heat treatment, alloy composition and phase constitution, and the initial alloy state before annealing, could influence the transformation and therefore affect the sizes, volume fractions, morphologies, and distributions of 18R and 14H LPSO phases [89-95].

Annealing temperature and time It is commonly accepted that the critical temperature for activating the transformation of LPSO phases is $350^{\circ} \mathrm{C}[89,90]$. The morphology and structure of LPSO phases usually remain the same when the $\mathrm{Mg}-\mathrm{RE}-\mathrm{Zn}$ cast alloys are heat treated at temperatures lower than $350{ }^{\circ} \mathrm{C}$. However, profuse stacking faults with concentrated solute atoms in the two faulted atomic layers are generated in the $\mathrm{Mg}_{97} \mathrm{Gd}_{2} \mathrm{Zn}_{1}$ alloy when the heat treatment temperature is around $300{ }^{\circ} \mathrm{C}$, which might be the precursor of $14 \mathrm{H}$ LPSO phase and could grow into $14 \mathrm{H}$ with elevated annealing temperatures [90]. Since the transformation of LPSO phase is a thermal activation process, increasing the temperature and holding time could actuate and accelerate this transformation. Most researches have already demonstrated that higher annealing temperatures greatly increased the growing rate of $14 \mathrm{H}$ phase, while the prolonged annealing time increased the dimensions and volume fractions of 14H lamellae [92-94].

Cooling mode and cooling rate After homogenization at high temperatures, the subsequent cooling process has a great influence on the progress and morphology of $14 \mathrm{H}$ lamellae. Li et al. [56] found that two kinds of $14 \mathrm{H}$ phase: block-like $14 \mathrm{H}$ at grain boundaries and needle-like $14 \mathrm{H}$ within $\alpha-\mathrm{Mg}$ grains, formed in the $\mathrm{Mg}-7 \mathrm{Gd}-3 \mathrm{Y}-1 \mathrm{Nd}-1 \mathrm{Zn}-0.5 \mathrm{Zr}$ (wt\%) alloys during homogenization. In the furnace cooling mode, block-like $14 \mathrm{H}$ phase disappeared at grain boundaries, but the needle-like $14 \mathrm{H}$ phase developed from grain boundaries to the whole grain interior. This is because the cooling mode with a lower cooling rate decreased the heat loss so that the diffusion of $\mathrm{Zn}$ and $\mathrm{RE}$ solute atoms proceeded fast and sufficiently, resulting in an explosive growth of needle-like (lamellar) $14 \mathrm{H}$ phase.

Alloy composition and phase constitution Liu et al. [93, 95] investigated the effect of alloy composition on the transformation behavior of $18 \mathrm{R} \rightarrow 14 \mathrm{H}$ in various $\mathrm{Mg}-\mathrm{Y}-\mathrm{Zn}$ alloys and found that the phase constitution, particularly the volume fraction of $\alpha-\mathrm{Mg}$ phase, exhibited a remarkable influence on the formation of $14 \mathrm{H}$ phase. In a nearly 18R-single-phase $\mathrm{Mg}_{86} \mathrm{Y}_{8} \mathrm{Zn}_{6}$ alloy (vol\%>93\%), the $18 \mathrm{R}$ block phase was thermal stable and was not transformed into $14 \mathrm{H}$ even after annealing at $500{ }^{\circ} \mathrm{C}$ for $240 \mathrm{~h}$. Only a very small number of $14 \mathrm{H}$ lamellae were generated in the sliceshaped $\alpha-\mathrm{Mg}$ phase $(\operatorname{vol} \%<1 \%)$ [95]. With the increase in volume fraction of $\alpha-\mathrm{Mg}$ phase, more $14 \mathrm{H}$ lamellae formed and propagated, covering the whole cellular $\alpha-\mathrm{Mg}$ grains of $\mathrm{Mg}_{88} \mathrm{Y}_{8} \mathrm{Zn}_{4}$ and $\mathrm{Mg}_{89} \mathrm{Y}_{8} \mathrm{Zn}_{3}$ alloys after a long time annealing at $500{ }^{\circ} \mathrm{C}$ [93]. In addition, as proved by $\mathrm{Mg}_{97} \mathrm{Y}_{2} \mathrm{Zn}_{1}$ or $\mathrm{Mg}_{95.5} \mathrm{Y}_{3} \mathrm{Zn}_{1.5}$ alloys in reported references [21, 89], with a further increased volume fraction of $\alpha-\mathrm{Mg}$ phase, not only were abundant $14 \mathrm{H}$ lamellae developed within the whole $\alpha-\mathrm{Mg}$ grains, but also the $18 \mathrm{R}$ block phases were gradually dissolved into the matrix.

Initial alloy state For the alloy with the same composition and constitution, the evolution behavior of LPSO phase during the same annealing process could be varied depending on the initial alloy state. A recent research showed that when annealing at $500{ }^{\circ} \mathrm{C}$, the $14 \mathrm{H}$ LPSO precipitated firstly in the cast $\mathrm{Mg}_{97} \mathrm{Y}_{2} \mathrm{Zn}_{1}$ alloy, but then dissolved into $\alpha-\mathrm{Mg}$, while the $18 \mathrm{R}$ phase exhibited no obvious change [91]. This phenomenon could be explained by the microsegregation in cast alloy state, which hindered the supply of solute atoms when $14 \mathrm{H}$ progressed within the $\alpha-\mathrm{Mg}$ grain. However, when the cast $\mathrm{Mg}_{97} \mathrm{Y}_{2} \mathrm{Zn}_{1}$ alloy was refined (extruded), its microstructure became homogeneous and the microsegregation was eliminated. Then, $14 \mathrm{H}$ formed and grew continuously, with $18 \mathrm{R}$ dissolved step by step, finally leading to a homogeneous $14 \mathrm{H} / \alpha-\mathrm{Mg}$ microstructure. Therefore, fine and dispersedly distributed 18R LPSO phase is more prone to dissolving into the matrix during annealing. Furthermore, in the case of the same alloy prepared by rapid solidification, the evolution behavior of LPSO phase becomes more complicated $[42,44]$.

\subsubsection{Formation Mechanism of 14H LPSO Phase}

Two main transformation mechanisms of $14 \mathrm{H}$ LPSO phase in $\mathrm{Mg}-\mathrm{RE}-\mathrm{Zn}$ alloys were established by experimental observations. The first one considered that $14 \mathrm{H}$ LPSO phase was directly transformed from 18R structures during high-temperature annealing [74]. The phenomena that 
18R network phase disappeared gradually, but $14 \mathrm{H}$ lamellar phases developed through the whole matrix during heat treatment were always observed in the $\mathrm{Mg}-\mathrm{Y}-\mathrm{Zn}$ alloys [91, 93]. It is widely accepted that $18 \mathrm{R}$ and $14 \mathrm{H}$ LPSO are phases at high temperature and low temperature, respectively, demonstrated by both experimental results [89] and thermodynamic calculation [25]. The atomic models of LPSO phases by Zhu et al. [74, 96] revealed that $18 \mathrm{R}$ unit cell was made of three ABCA-type building blocks with the same shear direction, while $14 \mathrm{H}$ unit cell consisted of two building blocks with opposite shears. Therefore, the $18 \mathrm{R}$ phase could be transformed into $14 \mathrm{H}$ structure spontaneously by the minimization of the shear strain energy associated with individual building blocks. Moreover, Zhu et al. $[18,20]$ characterized the direct transformation of $18 \mathrm{R}$ phase into $14 \mathrm{H}$ by HAADF-STEM observations. Figure 2 shows that an atomic model was proposed based on the HAADF-STEM result. By the gliding of two Shockley partials on two neighboring planes of $18 \mathrm{R}$, an $\mathrm{ABC} A$ building block was shifted upwards by one atomic layer and its stacking sequence changed to $\mathrm{ACB}$. Then, with the concomitant shuffle of $\mathrm{Y}$ and $\mathrm{Zn}$ atoms, a single unit cell of $14 \mathrm{H}$ was formed. Since only short-range movement of $\mathrm{Y}$ and $\mathrm{Zn}$ atoms by one atomic layer is required with no need of long-range diffusion of $\mathrm{Mg}$ atoms, this

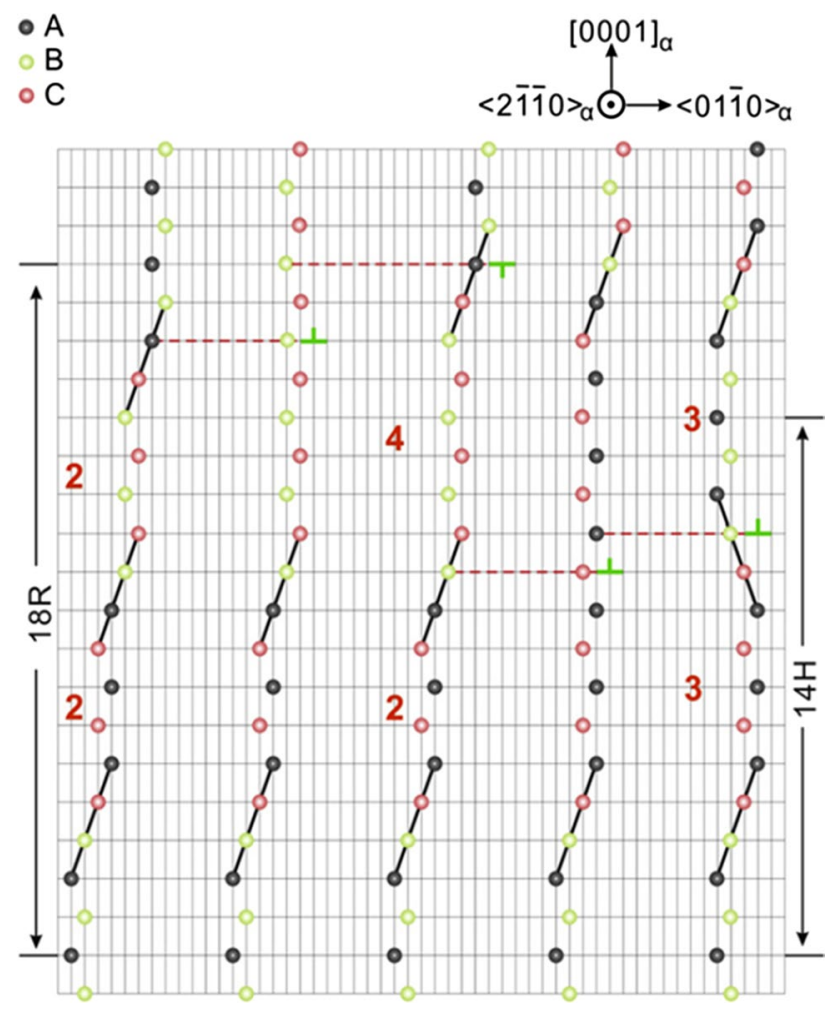

Fig. 2 Proposed model showing the transformation process from perfect $18 \mathrm{R}$ to $14 \mathrm{H}[18]$ diffusional-displacive transformation process is controlled by the diffusion rate of $\mathrm{Y}$ and $\mathrm{Zn}$ atoms into the faulted layers.

The second viewpoint suggests that the 14H LPSO phase is formed from the supersaturated $\alpha-M g$ grains $[90,91,93]$. Yamasaki et al. [90] investigated the precipitation behavior of a $\mathrm{Mg}_{97} \mathrm{Gd}_{2} \mathrm{Zn}_{1}$ alloy and found that at $400{ }^{\circ} \mathrm{C}$, the precipitation sequence is $\alpha-\mathrm{Mg} \rightarrow$ stacking fault $(\mathrm{SF}) \rightarrow 14 \mathrm{H}$ LPSO. Since no SFs were formed in the Mg-Gd binary alloys, they believed that the addition of $\mathrm{Zn}$ elements decreased the stacking fault energy and promoted the generation of SFs and $14 \mathrm{H}$ during annealing. Nie et al. [97] characterized the precipitates in $\mathrm{Mg}-\mathrm{Gd}-\mathrm{Zn}$ alloys via HAADF-STEM and proved that the SFs observed in early reports were actually $\gamma^{\prime}$ precipitates, which formed as plates of a single unit cell height on (0001) basal plane, and the length could be several microns (shown in Fig. 3a). In addition, the HAADF-STEM image in Fig. $3 b$ demonstrated that the stacking sequence of an $\gamma^{\prime}$ precipitate was -ABCACA-, the same as a LPSO building block (-ABCA-) [97]. Thus, $14 \mathrm{H}$ phase could form with the arrangement of $\gamma^{\prime}$ precipitate. For $\mathrm{Mg}-\mathrm{Y}-\mathrm{Zn}$ alloys, apart from the direct transformation from $18 \mathrm{R}$ phase, $14 \mathrm{H}$ could also be precipitated in this way. Zhu et al. [98] confirmed the existence of $\gamma^{\prime}$ precipitates in the $\mathrm{Mg}-\mathrm{Y}-\mathrm{Zn}$ alloy. Liu et al. $[91,93]$ also found that abundant SFs ( $\gamma^{\prime}$ precipitates, shown in Fig. 3c) formed in cast $\mathrm{Mg}-\mathrm{Y}-\mathrm{Zn}$ alloys with various compositions. Moreover, as shown in Fig. 3d, 14H lamellae could be precipitated directly from these SFs with the diffusion of solute atoms during heat treatment.

\subsection{Aging Treatment}

\subsubsection{Age Hardening of Cast Mg-RE-Zn Alloys}

T6 treatment (solid solution treatment and subsequent aging) is usually employed for the LPSO-containing $\mathrm{Mg}-\mathrm{RE}-\mathrm{Zn}$ alloys. Although the formation of LPSO phase consumes some RE elements, the $\alpha-\mathrm{Mg}$ matrix can still be supersaturated. In particular, when the alloys are solid solution treated first, parts of LPSO phases dissolve into the matrix, making the $\alpha-\mathrm{Mg}$ matrix more supersaturated and enhancing the age hardening response [21]. Table 1 summarizes the aging responses of $\mathrm{Mg}-\mathrm{RE}-\mathrm{Zn}$ alloys with LPSO phase reported in the last few years [32, 58, 59, 83, 99-101]. It is apparent that these alloys exhibit strong aging responses, with their hardness values increasing from 73-92 to 106-137 HV and with the increasing range of $21-45 \mathrm{HV}$. The solid solution temperatures are usually higher than $500{ }^{\circ} \mathrm{C}$, and the aging temperatures are $200-225^{\circ} \mathrm{C}$. Moreover, the higher the RE contents of the alloys, the shorter the time it is needed to reach peak aging states and the larger the hardness values for peak-aged alloys. 

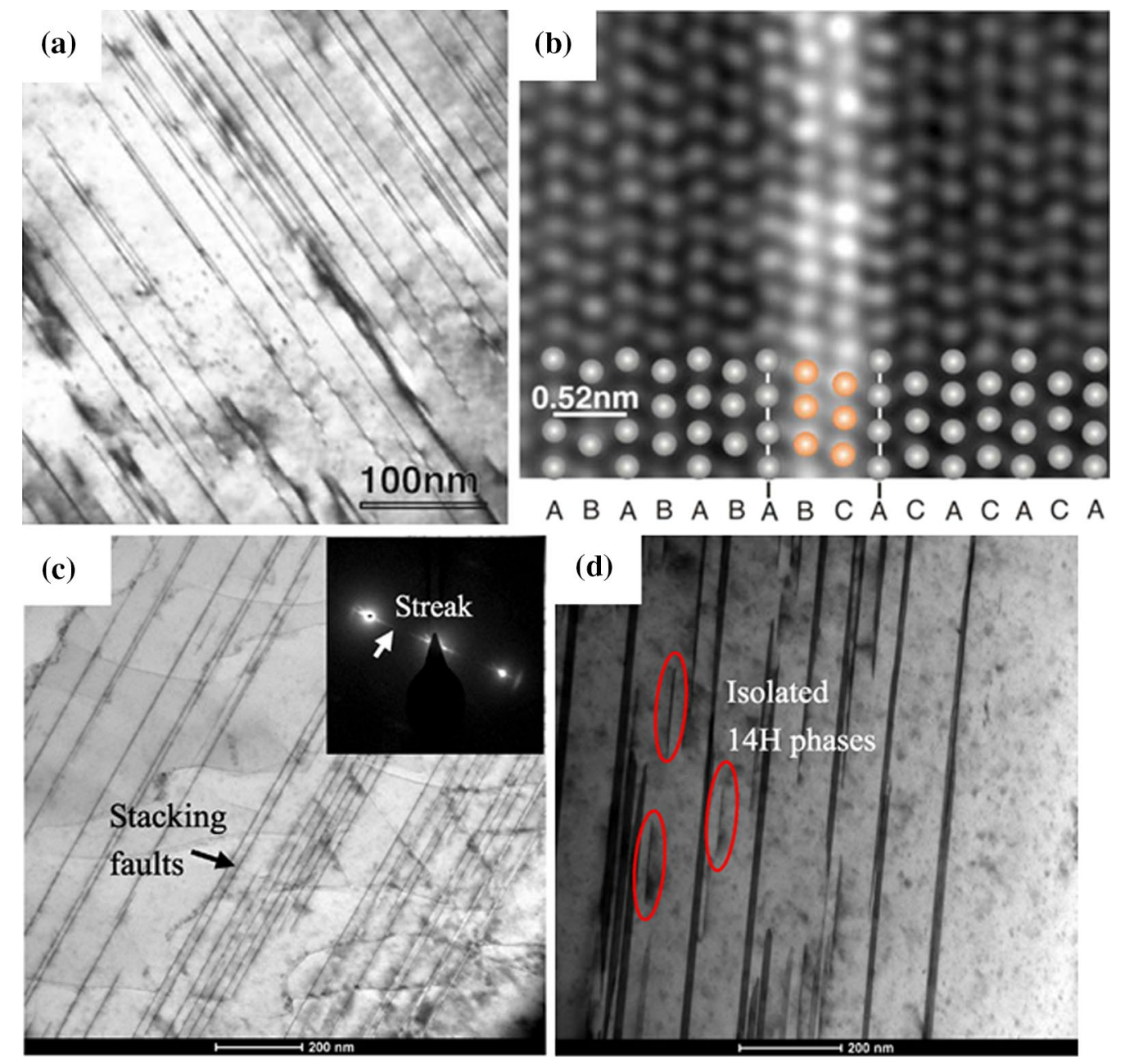

Fig. 3 Precipitates in Mg-Gd-Zn and Mg-Y-Zn alloys. a TEM and b HAADF-STEM images of $\gamma^{\prime}$ phase in Mg-Gd-Zn alloy [97]. $\mathbf{c}$ SFs in $\mathrm{Mg}-\mathrm{Y}-\mathrm{Zn}$ alloy before heat treatment, $\mathbf{d}$ 14H LPSO phase formed after heat treatment [91]

Table 1 Aging response of LPSO-containing Mg-REZn-based casting alloys

\begin{tabular}{|c|c|c|c|c|}
\hline Alloys (wt\%) & Aging treatment & $\begin{array}{l}\text { Initial hard- } \\
\text { ness (HV) }\end{array}$ & $\begin{array}{l}\text { Peak hard- } \\
\text { ness (HV) }\end{array}$ & References \\
\hline $\mathrm{Mg}-9.53 \mathrm{Gd}-3.24 \mathrm{Y}-1.69 \mathrm{Zn}$ & $520^{\circ} \mathrm{C} / 8 \mathrm{~h}+220^{\circ} \mathrm{C} / 142 \mathrm{~h}$ & 85 & 106 & {$[83]$} \\
\hline $\mathrm{Mg}-9.85 \mathrm{Gd}-2.94 \mathrm{Y}-1.57 \mathrm{Zn}-0.4 \mathrm{Zr}$ & $520^{\circ} \mathrm{C} / 8 \mathrm{~h}+220^{\circ} \mathrm{C} / 126 \mathrm{~h}$ & 85 & 110 & \\
\hline $\mathrm{Mg}-9.92 \mathrm{Gd}-2.87 \mathrm{Y}-1.61 \mathrm{Zn}-0.4 \mathrm{Ti}$ & $520^{\circ} \mathrm{C} / 8 \mathrm{~h}+220^{\circ} \mathrm{C} / 132 \mathrm{~h}$ & 84 & 113 & \\
\hline $\mathrm{Mg}-9.87 \mathrm{Gd}-3.06 \mathrm{Y}-1.73 \mathrm{Zn}-0.6 \mathrm{Ti}$ & $520^{\circ} \mathrm{C} / 8 \mathrm{~h}+220^{\circ} \mathrm{C} / 136 \mathrm{~h}$ & 86 & 116 & \\
\hline $\mathrm{Mg}-9.78 \mathrm{Gd}-2.91 \mathrm{Y}-1.52 \mathrm{Zn}-0.8 \mathrm{Ti}$ & $520^{\circ} \mathrm{C} / 8 \mathrm{~h}+220^{\circ} \mathrm{C} / 142 \mathrm{~h}$ & 87 & 118 & \\
\hline $\mathrm{Mg}-15 \mathrm{Gd}-0.4 \mathrm{Zr}$ & $520^{\circ} \mathrm{C} / 12 \mathrm{~h}+200^{\circ} \mathrm{C} / 64 \mathrm{~h}$ & 73 & 121 & {$[58]$} \\
\hline $\mathrm{Mg}-15 \mathrm{Gd}-1 \mathrm{Zn}-0.4 \mathrm{Zr}$ & $520^{\circ} \mathrm{C} / 12 \mathrm{~h}+200^{\circ} \mathrm{C} / 64 \mathrm{~h}$ & 83 & 127 & \\
\hline $\mathrm{Mg}_{96.34} \mathrm{Gd}_{2.5} \mathrm{Zn}_{1} \mathrm{Zr}_{0.16}$ (at.\%) & $\begin{array}{l}480{ }^{\circ} \mathrm{C} / 12 \mathrm{~h}+200^{\circ} \mathrm{C} / 32 \mathrm{~h} \\
500^{\circ} \mathrm{C} / 10 \mathrm{~h}+200^{\circ} \mathrm{C} / 128 \mathrm{~h} \\
520^{\circ} \mathrm{C} / 12 \mathrm{~h}+200^{\circ} \mathrm{C} / 64 \mathrm{~h}\end{array}$ & 81 & $\begin{array}{l}110 \\
116 \\
122\end{array}$ & {$[59]$} \\
\hline $\mathrm{Mg}-12 \mathrm{Gd}-2 \mathrm{Er}-1 \mathrm{Zn}-0.6 \mathrm{Zr}$ & $520^{\circ} \mathrm{C} / 24 \mathrm{~h}+225^{\circ} \mathrm{C} / 84 \mathrm{~h}$ & 85 & 120 & {$[32]$} \\
\hline $\mathrm{Mg}-11 \mathrm{Y}-5 \mathrm{Gd}-2 \mathrm{Zn}-0.5 \mathrm{Zr}$ & $535^{\circ} \mathrm{C} / 20 \mathrm{~h}+225^{\circ} \mathrm{C} / 24 \mathrm{~h}$ & 92 & 137 & [99] \\
\hline $\mathrm{Mg}-14 \mathrm{Gd}-3 \mathrm{Y}-1.8 \mathrm{Zn}-0.5 \mathrm{Zr}$ & $525^{\circ} \mathrm{C} / 10 \mathrm{~h}+225^{\circ} \mathrm{C} / 16 \mathrm{~h}$ & 84 & 127 & {$[100]$} \\
\hline $\mathrm{Mg}-12.56 \mathrm{Y}-4.88 \mathrm{Gd}-1.3 \mathrm{Zn}-0.33 \mathrm{Zr}$ & $535^{\circ} \mathrm{C} / 16 \mathrm{~h}+225^{\circ} \mathrm{C} / 24 \mathrm{~h}$ & 119 & 153 & {$[101]$} \\
\hline
\end{tabular}




\subsubsection{Precipitation behavior of $\mathrm{Mg}-\mathrm{RE}-\mathrm{Zn}$ alloys}

Two series of precipitation behaviors were widely observed for the LPSO-containing Mg-RE-Zn alloys. The first precipitation sequence includes the formation of $\beta^{\prime \prime}, \beta^{\prime}\left(\beta_{1}\right)$ and $\beta$ phases, which is identical to precipitates in $\mathrm{Mg}-\mathrm{Gd}$ [102] or Mg-Y [103] alloys without $\mathrm{Zn}$ addition. Moreover, some reports also suggested that the $\beta^{\prime \prime}$ phase did not exist in this precipitation sequence [104-106]. Saito et al. [104] examined the precipitates in a $\mathrm{Mg}-\mathrm{Nd}$ alloy via HAADF-STEM analysis and confirmed a planar GP-zones appeared in parallel to $(100)_{\alpha-M g}$ planes with a thickness of sub-nanometer and a length of 5-15 nm. However, the $\beta^{\prime \prime}$ precipitates were not observed by HAADF-STEM. Issa et al. [105] assessed the binary $\mathrm{Mg}-\mathrm{RE}$ aging reactions using first principles calculations and pointed out that the $\mathrm{Mg} / \beta^{\prime \prime}$ prismatic interfaces exhibited a negative interfacial energy and thus were unstable. The atomically thin $\beta^{\prime \prime}$ planar Guinier-Preston (GP) zones can form as a precursor to $\beta^{\prime}$ precipitation. More recently, Nie et al. [106] also demonstrated the absence of $\beta^{\prime \prime}$ precipitates in the early stage of $\mathrm{Mg}-\mathrm{Nd}$ and $\mathrm{Mg}-\mathrm{Y}$ aged alloys via a combination of atomic resolution HAADF-STEM characterization and first principles density functional theory computations. However, whether $\beta^{\prime \prime}$ precipitates appear in $\mathrm{Mg}-\mathrm{RE}$ binary alloys still remains a question mark. Thus, more efforts are needed to verify the precipitation in early aging stage of these alloys, as well as in Mg-RE-TM ternary alloys. The second precipitating sequence is SSSS $\rightarrow \gamma^{\prime \prime} \rightarrow \gamma^{\prime} \rightarrow \gamma(14 \mathrm{H}$ LPSO), reported most in Mg-RE-Zn alloys [97].

The peak aging states of $\mathrm{Mg}-\mathrm{RE}$-based alloys usually correspond to the prosperous precipitation of $\beta^{\prime}$ (and $\beta_{1}$ ) phase or $\gamma^{\prime \prime}$ phase [97, 107]. In particular, these two series of precipitations could occur in the same alloy during aging, as was reported recently by Fu et al. [107] in $\mathrm{Mg}-\mathrm{Gd}-\mathrm{Zn}-\mathrm{Zr}$ alloys. Figure $4 \mathrm{a}$ and $\mathrm{b}$ shows the HAADFSTEM images of $\beta^{\prime}$ and $\beta_{1}$ precipitates [108]. The $\beta^{\prime}$ precipitates usually form in a lenticular shape with a basecentered orthorhombic (bco) structure. Its orientation relationship with $\alpha-\mathrm{Mg}$ is identified to be $(001)_{\beta^{\prime}} / /(0001)_{\alpha}$ and $[100]_{\beta^{\prime}} / /[2 \overline{1} \overline{1} 0]_{\alpha}$. The $\beta_{1}$ phase has a face-centered cubic (fcc) structure, and it favors to nucleate adjacent to $\beta^{\prime}$ precipitates.

Figure 4c-e shows the HAADF-STEM morphology of $\gamma^{\prime \prime}$ precipitates [109]. Most $\gamma^{\prime \prime}$ precipitates have a high aspect ratio of more than 40:1. The $\gamma^{\prime \prime}$ precipitates exhibit a plate shape with their habit plane parallel to basal plane of $\alpha-\mathrm{Mg}$. The orientation relationship between $\gamma^{\prime \prime}$ precipitate and $\alpha-\mathrm{Mg}$ matrix is $(0001)_{\gamma^{\prime \prime}} / /(0001)_{\alpha}$ and $[10 \overline{1} 0]_{\gamma^{\prime \prime}}$ $/ /[2 \overline{1} 10]_{\alpha}[97,104]$. So far, the detailed atomic structure of $\gamma^{\prime \prime}$ precipitates is controversial. It is accepted that the $\gamma^{\prime \prime}$ phase consists of three atomic layers paralleling to $(0001)_{\alpha}$ basal plane, where Gd and/or Zn atoms occupy ordered

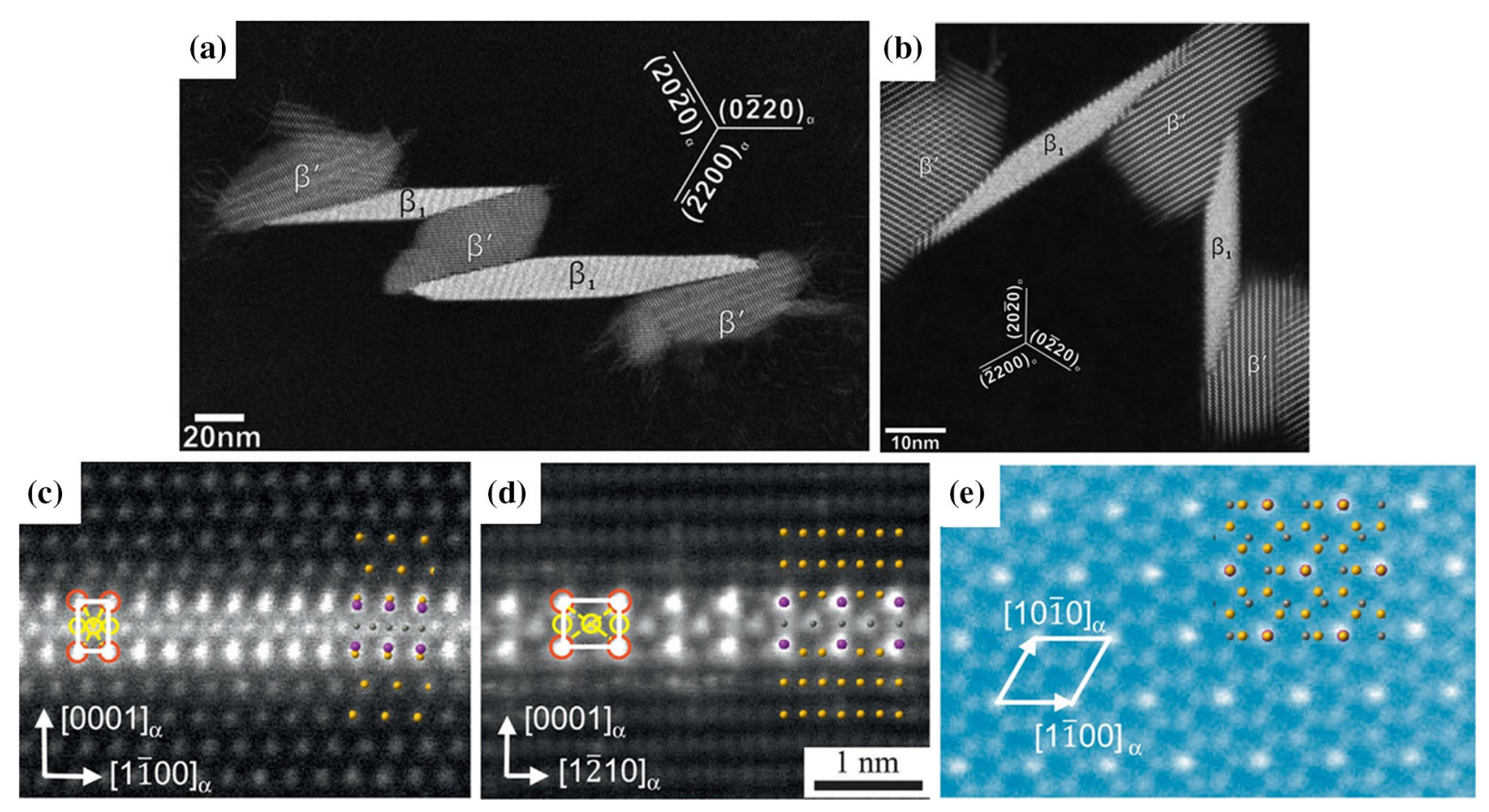

Fig. 4 HAADF-STEM images of the various precipitates in Mg-RE-TM alloys. a, b $\beta^{\prime}$ and $\beta_{1}$ precipitates viewed from [0001] $]_{\alpha}$ direction [108]. Atomic structure of $\gamma^{\prime \prime}$ precipitates viewed from $\mathbf{c}[11 \overline{2} 0]_{\alpha}, \mathbf{d}[10 \overline{1} 0]_{\alpha}, \mathbf{e}[0001]_{\alpha}$ directions [109] 
positions $(0,0,0)$ in the outer two layers, but the atomic positions in the middle layer of the structure are not unambiguously determined [97, 110-112]. More recently, by employment of HAADF-STEM, Gu et al. [109] proposed the atomic structure of $\gamma^{\prime \prime}$ phase as a hexagonal structure with lattice parameters as $a=0.556 \mathrm{~nm}$ and $c=0.39 \mathrm{~nm}$, and $\mathrm{Gd}$ atoms locate at $(0,0,0)$ position, $\mathrm{Mg}$ locate at $(1 / 3$, $1 / 3,0)$ and $(2 / 3,2 / 3,0)$, and $\mathrm{Zn}$ locate at $(1 / 2,1 / 2,1 / 2)$, $(1 / 2,0,1 / 2)$, and $(0,1 / 2,1 / 2)$, as shown in Fig. $4 c-e$. Furthermore, they compared this model with the existing models in literature by first principles calculation and showed that all of the structure models reported were not stable and relaxed to a structure close to the present model.

\subsubsection{Interaction Between Precipitates and LPSO Structure}

Since precipitating behavior commonly occurred in $\mathrm{Mg}-\mathrm{RE}-\mathrm{Zn}$ alloys, the precipitates could coexist or interact with LPSO phases, which plays an important role in improving the mechanical properties of these alloys. The typical morphology exhibiting the coexistence of $\beta^{\prime}$ precipitates and LPSO phase is shown in Fig. 5a [113]. It is apparent that they usually form an intercalated structure. This is because the basal LPSO lamellar phase (especially $14 \mathrm{H}$ structure) always forms a sandwich structure with $\alpha-\mathrm{Mg}$ slices, and the $\beta^{\prime}$ precipitates form on the prismatic planes of $\alpha-\operatorname{Mg}[18,102]$. Figure $5 b$ presents the schematic spatial distribution relationship between $\beta^{\prime}$ precipitates and LPSO structures [113]. The LPSO phase exists in cast or annealed $\mathrm{Mg}-\mathrm{RE}-\mathrm{Zn}$ alloys (annealing temperature above $350^{\circ} \mathrm{C}$ ), while $\beta^{\prime}$ precipitates form during aging at lower temperatures $\left(180-250^{\circ} \mathrm{C}\right)$. As long as the density and sizes of $\beta^{\prime}$ precipitates grow large enough, they begin to interact with the neighboring LPSO structures, and thus, the growth of $\beta^{\prime}$ precipitates along $[0001]_{\alpha}$ direction is restrained by the lamellar LPSO phase, forming a sandwich or intercalated 3-D structure. In other words, the lamellar LPSO structure suppresses the growth of $\beta^{\prime}$ phases, which could improve the strengthening effect of these precipitates.

Chen et al. characterized the $\beta^{\prime} /$ LPSO interfaces in an $\mathrm{Mg}-10 \mathrm{Gd}-5 \mathrm{Y}-2 \mathrm{Zn}-0.5 \mathrm{Zr}$ aged alloy using HAADF-STEM and confirmed three types of interfaces [113]. The first type (type-I) is shown in Fig. 6a. A straight gap with a width of about $1.3 \mathrm{~nm}$ exists between $\beta^{\prime}$ and LPSO phase. In detail, this gap is composed of four RE/Zn-free atomic layers and the width of $1.3 \mathrm{~nm}$ corresponds to the theoretic distance of four pure $\mathrm{Mg}$ atomic layers. Figure $6 \mathrm{~b}$ displays a typeII interface where redistributions of heavy atoms within LPSO structures happen. The periodicity of redistributed RE-enriched layers is $1.1 \mathrm{~nm}$, which is approximately equivalent to the distance of 5 atomic sites along $[10 \overline{1} 0]_{\alpha}$ direction, and also corresponds to the distance between two adjacent RE zigzag lines in $\beta^{\prime}$ structure. Furthermore, as shown in Fig. $6 \mathrm{c}$, the $\beta^{\prime}$ precipitates are intercepted by LPSO structures from $[10 \overline{1} 0]_{\alpha}$ direction, which is categorized as a type-III interaction. In the case of $\gamma^{\prime \prime}$ or $\gamma^{\prime}$ precipitates, since they are parallel with LPSO lamellae along the basal plane, interaction between these precipitates and LPSO phase is seldom investigated.

\section{Rapid Solidification (RS)}

Rapid solidification (RS) is an effective way to prepare magnesium alloys with modified microstructures, such as segregation-less structure, nanocrystalline, supersaturated solid solution, and metastable phases [5, 39, 41-43]. To obtain high-performance magnesium alloys, two main

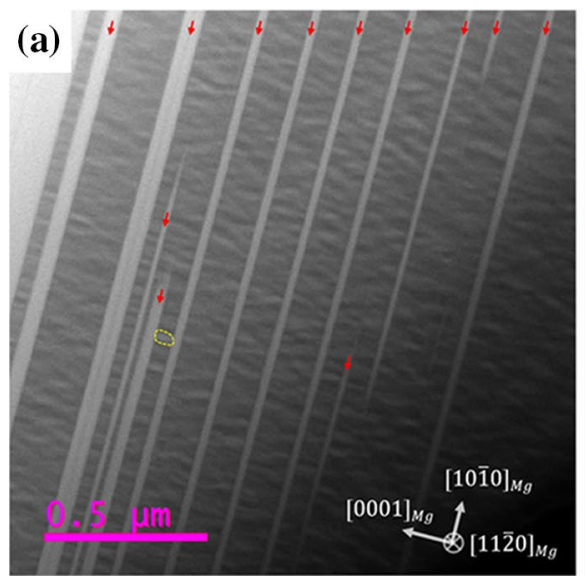

Fig. 5 a General morphology of LPSO structures intercalated with $\beta^{\prime}$ precipitates (LPSO phases are denoted by red arrows; an $\beta^{\prime}$ precipitate is denoted by yellow curve). Incident beam $/[11 \overline{2} 0] \mathrm{Mg}$; b sche-

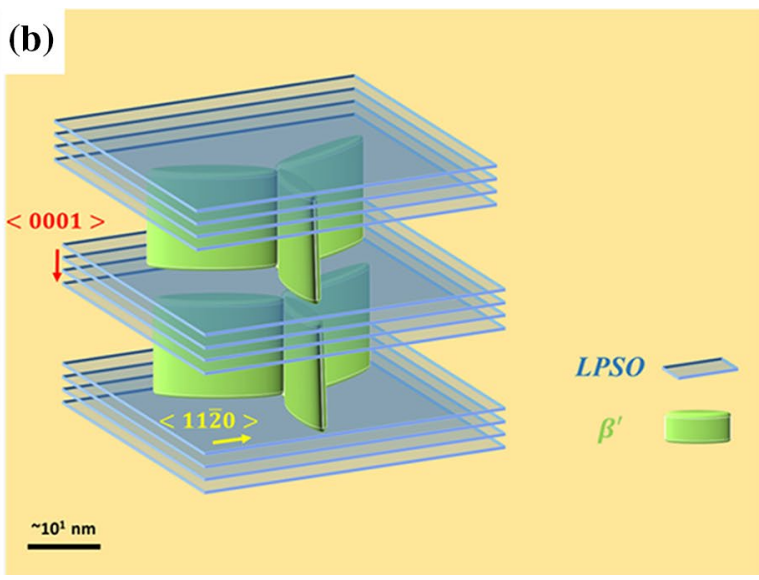

matic diagram illustrating the spatial relationship between $\beta^{\prime}$ precipitates and LPSO structures [113] 

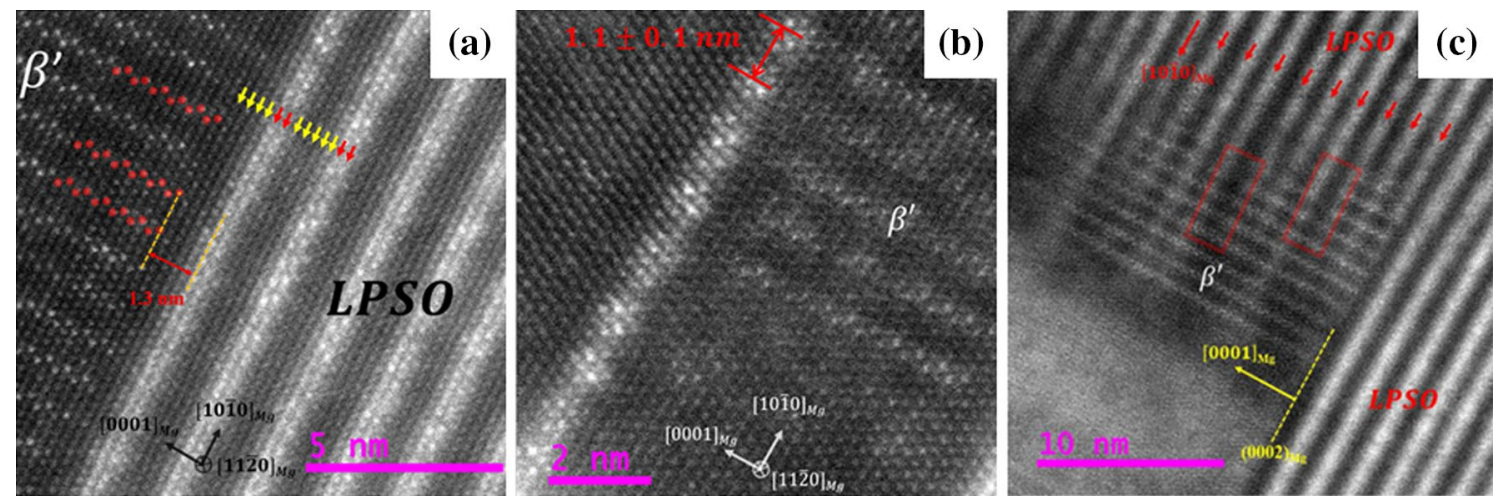

Fig. 6 HAADF-STEM images presenting three types of $\beta^{\prime} /$ LPSO interfaces. a RE-absent gaps parallel to $(11 \overline{2} 0) \mathrm{Mg}$ with a width about $1.3 \mathrm{~nm}$. b Redistribution of the heavy atoms in LPSO close to $\beta^{\prime}$ precipitates. c A $\beta^{\prime}$ precipitate intercepted by LPSO. Incident beam/ $/[11 \overline{2} 0]_{\alpha}[113]$

rapid solidification techniques: rapidly solidified powders metallurgy (RS/PM) [5, 39] and melt spinning [41-43], have already been used to prepare these LPSO-containing Mg-RE-Zn alloys.

\subsection{Rapidly Solidified Powders Metallurgy (RS/PM)}

The RS/PM method includes four procedures: induction melting, gas atomization, cold pressing and hot extrusion. The gas atomization procedure mainly determines the RS microstructure, and a typical close-coupled nozzle ultrasonic atomization system is shown in Fig. 7 [39]. Using the RS/PM method, Kawamura et al. [5] first fabricated an $\mathrm{Mg}_{97} \mathrm{Y}_{2} \mathrm{Zn}_{1}$ alloy and found that the prepared alloy exhibited excellent mechanical properties at both room temperature and elevated temperatures. Abe et al. [40] examined the microstructure of this RS/PM alloy by HAADF-STEM and confirmed the existence of a lamellar 6H LPSO phase within the nanosized $\alpha-\mathrm{Mg}$ grains (Fig. 8a). This $6 \mathrm{H}$ LPSO structure was demonstrated to be 18R LPSO structure, as seen from the SAED patterns in Fig. 8b, d [39, 40]. Zhu et al. [39] further investigated the contents and atomic ratios of $\mathrm{Y}$ and $\mathrm{Zn}$ elements on phase constitutions of the RS/PM $\mathrm{Mg}-\mathrm{Y}-\mathrm{Zn}$ alloys. Similar to the conventional cast alloy, the $\mathrm{RS} / \mathrm{PM}$ alloys have a microstructure closely related to the $\mathrm{Y} / \mathrm{Zn}$ atomic ratio. A higher $\mathrm{Y} / \mathrm{Zn}$ ratio (2 or 1.5) promoted the formation of the $\alpha-\mathrm{Mg} / 18 \mathrm{R}$ LPSO two-phase microstructure, while a lower ratio of 1 or 0.75 favored the formation of $\mathrm{Mg}_{3} \mathrm{Y}_{2} \mathrm{Zn}_{3}$ particles. Moreover, it was found that LPSO phase is most easily obtained when the $\mathrm{Y} / \mathrm{Zn}$ ratio is 1.5 , which is little different from the convention cast alloys $(\sim 2)$. This might be caused by the fast cooling rate. Figure 8 shows the TEM images of two typical RS/PM alloys. The volume fraction of LPSO phase in $\mathrm{Mg}_{97} \mathrm{Y}_{2} \mathrm{Zn}_{1}$ alloy (Fig. 8a) is relatively lower than that in the same alloy fabricated by conventional casting [91]. As the solute atoms increased, abundant

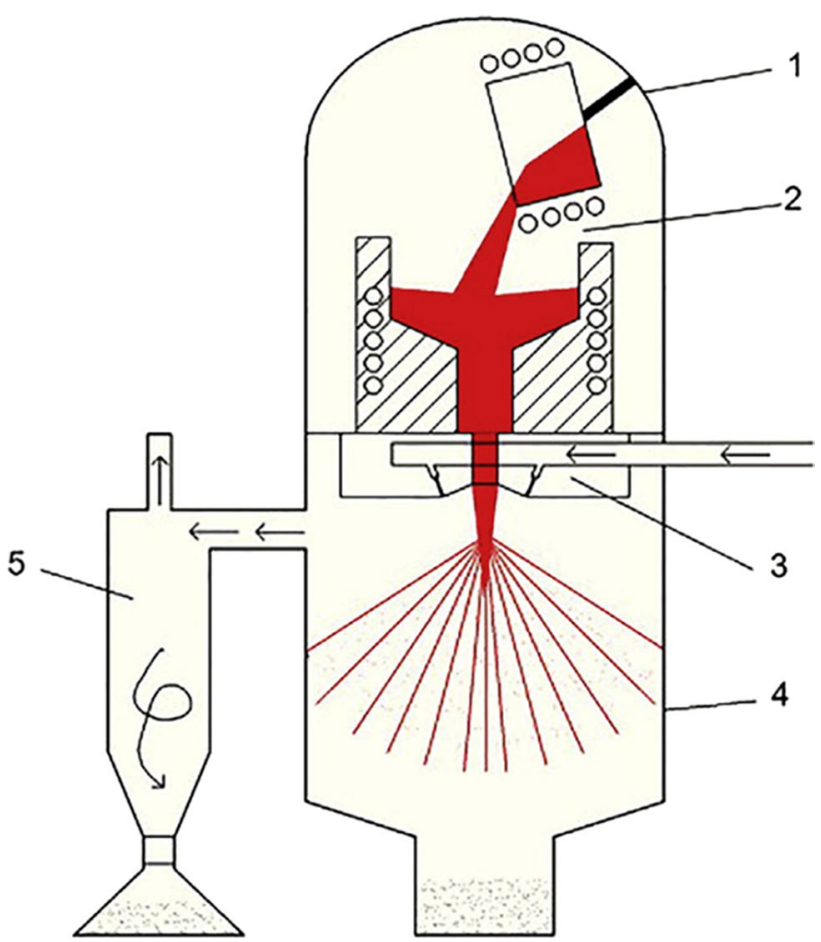

Fig. 7 Schematic of close-coupled nozzle ultrasonic atomization system: (1) melting chamber, (2) induction coil, (3) nozzle system, (4) atomization chamber, (5) cyclone separator [39]

lath-shaped LPSO phase was generated in the $\mathrm{Mg}_{91} \mathrm{Zn}_{3.6} \mathrm{Y}_{5.4}$ alloy (Fig. 8b), almost covering the whole $\alpha-\mathrm{Mg}$ grains [39].

\subsection{Melt Spinning}

Typical microstructure of $\mathrm{Mg}-\mathrm{Zn}-\mathrm{Y}$ melt spun ribbons was usually characterized by supersaturated $\alpha-\mathrm{Mg}$ grains with a grain size of around $200 \mathrm{~nm}$ and primary LPSO phase segregated at grain boundaries, which is different from the RS/PM alloys [41]. Garcés et al. [41] studied the formation 

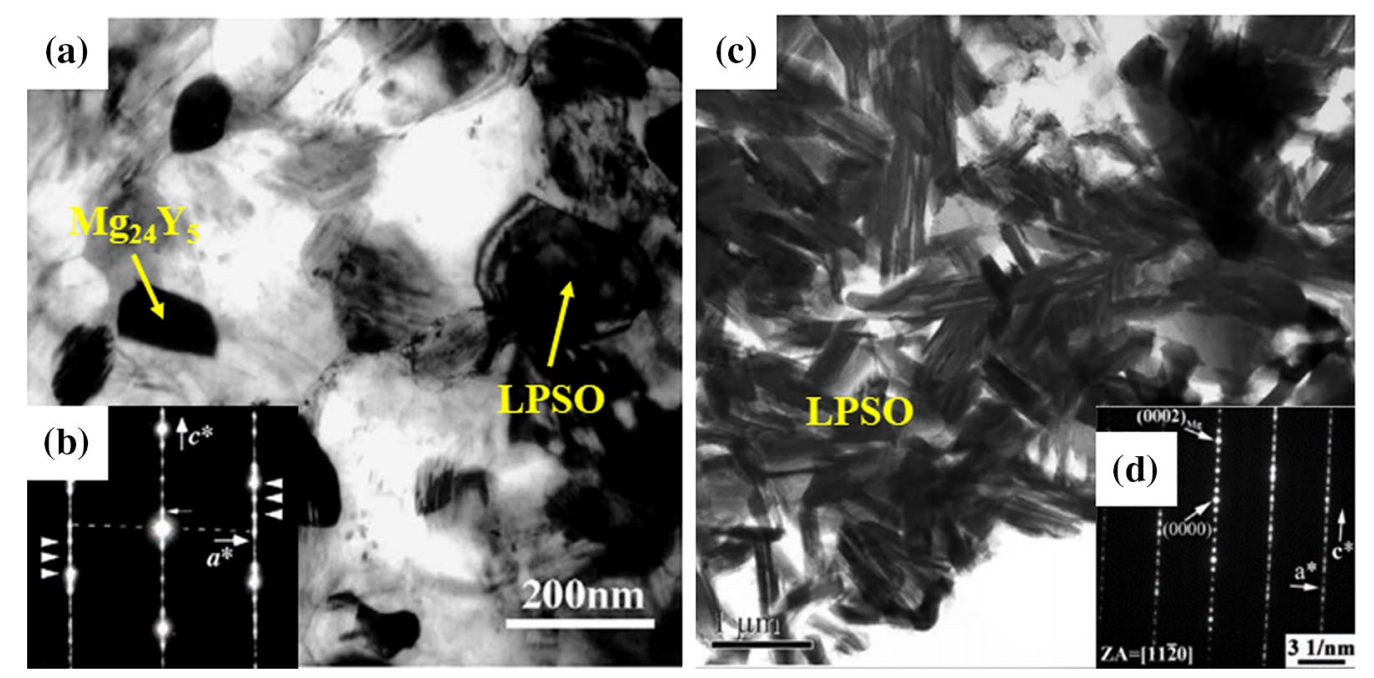

Fig. 8 TEM images of RS/PM Mg-Y-Zn alloys: a $\mathrm{Mg}_{97} \mathrm{Zn}_{1} \mathrm{Y}_{2}$, b SAED pattern of LPSO phase in a [40], $\mathbf{c} \mathrm{Mg}_{91} \mathrm{Zn}_{3.6} \mathrm{Y}_{5.4}$, $\mathbf{d}$ SAED pattern of LPSO phase in $\mathbf{c}$ [39]

mechanism of 18R LPSO in melt spun processing using high energy X-ray synchrotron radiation diffraction during in situ isochronal heating. The formation of $18 \mathrm{R}$ in $\mathrm{RS}$ ribbon followed the same process as proposed by Zhu et al. [18] in conventional cast alloy. They also estimated the apparent activation energy of the formation of 18R LPSO phase to be $125 \mathrm{~kJ} / \mathrm{mol}$, which corresponded to the activation energy for diffusion of $\mathrm{Y}$ and $\mathrm{Zn}$ atoms along the $\mathrm{Mg}$ basal plane. In addition, when $\mathrm{Y}$ element was partially replaced by cheaper mischmetal, LPSO structure was also observed in the melt spun Mg-Zn-Y-LaMM alloys [43].

\subsection{Heat Treatment of RS Alloys}

Since metastable microstructure is obtained after RS processing, the morphology or transformation of various LPSO phases during heat treatment became more complicated when compared with the corresponding conventional casting alloys. The temperature for transformation of $18 \mathrm{R}$ to $14 \mathrm{H}$ is usually above $350{ }^{\circ} \mathrm{C}$ for conventional casting alloys, but it decreases for RS alloy. Liu et al. [42] prepared the melt spun $\mathrm{Mg}-7 \mathrm{Y}-4 \mathrm{Gd}-5 \mathrm{Zn}-0.4 \mathrm{Zr}$ alloy and found that at a low annealing temperature of $300{ }^{\circ} \mathrm{C}$, transformation of $18 \mathrm{R}$ to $14 \mathrm{H}$ phase occurred after $0.5 \mathrm{~h}$. With increasing holding time to $5 \mathrm{~h}$, a new precipitate of $14 \mathrm{H}$ was also formed within supersaturated $\alpha-\mathrm{Mg}$ grains. And this precipitation process accelerated at a higher annealing temperature of $500{ }^{\circ} \mathrm{C}$ for just $0.5 \mathrm{~h}$. Moreover, annealing of the melt spun alloy stimulated the appearance of various types of LPSO phases. Matsuda et al. [16] found that four kinds of LPSO phases: $10 \mathrm{H}, 14 \mathrm{H}, 18 \mathrm{R}$ and $24 \mathrm{R}$, were identified when the melt spun $\mathrm{Mg}_{97} \mathrm{Zn}_{1} \mathrm{Y}_{2}$ alloy was annealed at $573 \mathrm{~K}$ for $1 \mathrm{~h}$. And these various LPSO structures could even coexist within the same grains. As demonstrated by HAADF-STEM, the four LPSO structures were made of $\boldsymbol{A B C A}$-type building blocks with 1-4 Mg layers intersected between them [20]. Therefore, due to the disorder of LPSO phase caused by rapid solidification, subsequent heat treatment will induce metastable LPSO structures before the stable $14 \mathrm{H}$ LPSO phase forms completely. The coexistence of $14 \mathrm{H}$ with $18 \mathrm{R}$ and $24 \mathrm{R}$ structures has also been reported in heat treatment of the conventional casting $\mathrm{Mg}-\mathrm{Y}-\mathrm{Zn}$ alloys [18].

\section{Other Novel Casting Techniques}

\subsection{Directional Solidification (DC)}

The LPSO phase exhibits obvious mechanical anisotropy, and the highest strength is attained in the $[0001]_{\text {LPSO }}$ direction [114, 115]. Therefore, preparation of $\mathrm{Mg}-\mathrm{RE}-\mathrm{Zn}$ alloys with LPSO phase arranged in the preferential orientation might be a good approach for novel high-strength magnesium alloys. By now, only limited work has explored the DC Mg-RE-Zn alloys. Hagihara et al. [52] prepared a near single-phase DC $\mathrm{Mg}_{88} \mathrm{Zn}_{5} \mathrm{Y}_{7}$ alloy (with LPSO volume fraction more than $85 \%$ ) using Bridgman technique. The microstructure of the DC alloy observed in the longitudinal and transverse sections along the growth direction is shown in Fig. 9a, b [52], respectively, and a schematic illustration of the DC microstructure is shown in Fig. 9c [48]. It can be seen that the 18R-LPSO grains exhibit a lath shape (or plate shape) with a thickness of $100 \mu \mathrm{m}$ and a length of over a few millimeters. These 18R laths grow with their longitudinal direction (basal plane) parallel to the DC direction. When observed in the transverse 

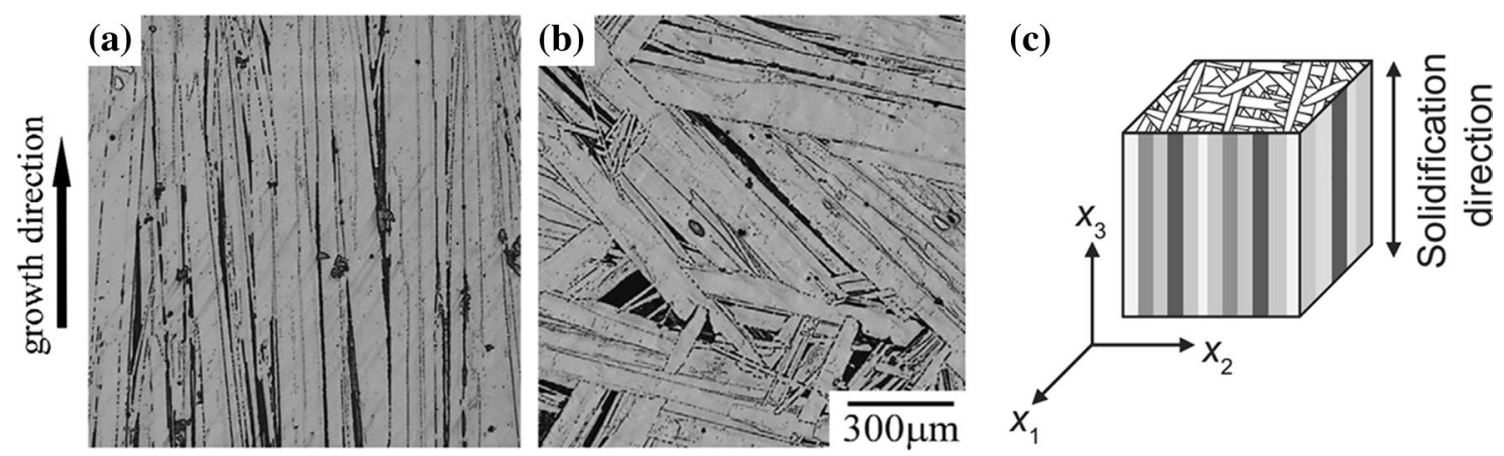

Fig. 9 OM images of the DS crystal microstructure observed in the a longitudinal and $\mathbf{b}$ transverse sections along the growth direction [52]. $\mathbf{c}$ Schematic illustration showing the microstructure in a DS polycrystal [48]

sections, however, the $18 \mathrm{R}$ grains are randomly arranged. Similar to the conventional $\mathrm{Mg}-\mathrm{RE}-\mathrm{Zn}$ casting alloys, the DC $\mathrm{Mg}_{88} \mathrm{Zn}_{5} \mathrm{Y}_{7}$ alloy witnessed the generation of the $14 \mathrm{H}$ LPSO phase when subjected to a high annealing temperature of $525{ }^{\circ} \mathrm{C}$ for 3 days [51]. Further investigations also confirmed the same phenomena in $\mathrm{Mg}_{85} \mathrm{Zn}_{6} \mathrm{Y}_{9}$ and $\mathrm{Mg}_{85} \mathrm{Zn}_{7} \mathrm{Y}_{8}$ alloys [46]. Interestingly, the structure of LPSO phase formed in DC alloys varies with different alloy compositions. For example, the DC $\mathrm{Mg}_{75} \mathrm{Zn}_{10} \mathrm{Y}_{15}$ alloy with higher concentrations of $\mathrm{Zn}$ and $\mathrm{Y}$ elements predominantly contained $10 \mathrm{H}$ LPSO phases [46, 47], while in the $\mathrm{Mg}_{98.5} \mathrm{Zn}_{0.5} \mathrm{Y}_{1}$ alloy with much lower solute atoms contents, $14 \mathrm{H}$ LPSO lamellae directly formed in as-DC state [53]. This implies that not only the DC technical parameters, but also the alloy compositions have great impacts on the formation and morphology of LPSO phases, which might be determined by the diffusions of solute atoms. The underlying mechanisms need to be further dissected.

\subsection{Ultrasonic Treatment (UT)}

Lü et al. [116] recently employed ultrasonic treatment to prepare the LPSO-containing $\mathrm{Mg}-\mathrm{Y}-\mathrm{Ni}$ alloys and comparatively investigated the microstructures and mechanical properties of alloys with and without UT. By introducing UT to the melt, the 18R LPSO phases were refined significantly and distributed uniformly in the $\mathrm{Mg}_{98.5} \mathrm{Ni}_{0.5} \mathrm{Y}_{1.0}$ alloy, which remarkably increased its ultimate tensile strength from 206 to $231 \mathrm{MPa}$ and elongation from 7.96 to $14.56 \%$, respectively.

\section{Mechanical Properties of Cast Alloys}

\subsection{Room-Temperature Mechanical Properties}

Compared with conventional commercial magnesium alloys, the LPSO-containing alloys exhibit higher mechanical properties. Figure 10 shows the room-temperature ultimate tensile
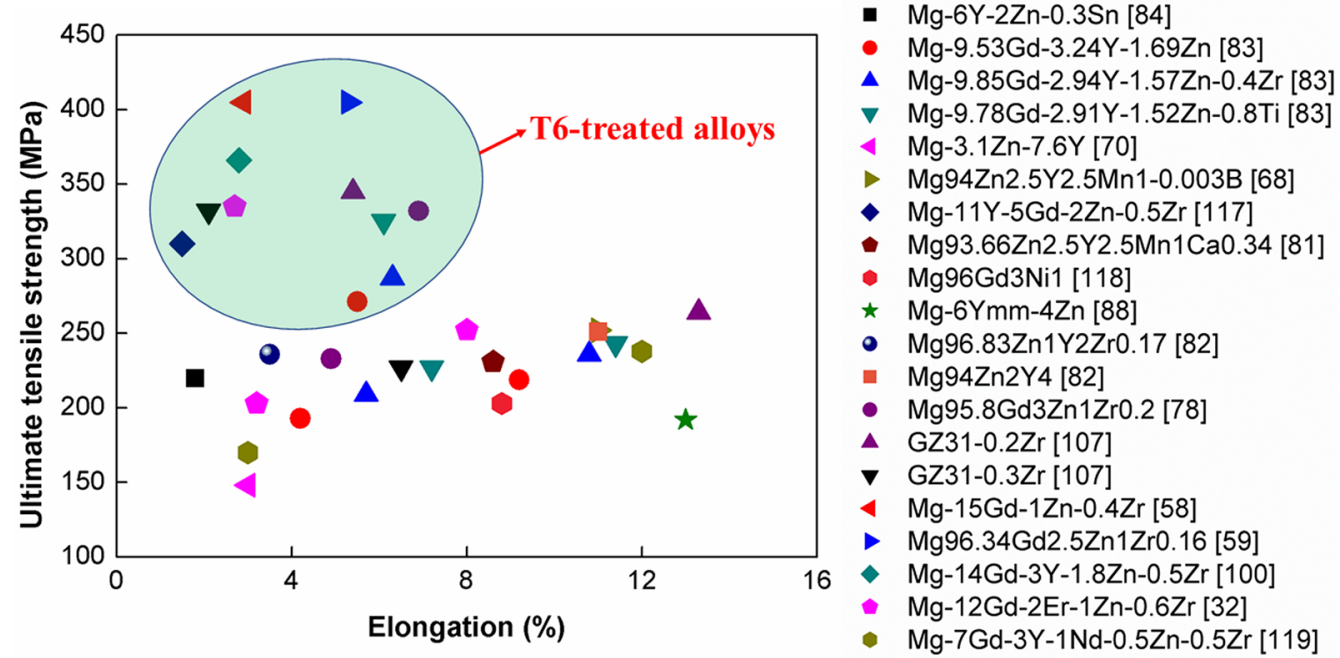

Fig. 10 Tensile properties of LPSO-containing Mg-RE casting alloys at room temperature 
strengths and elongations of casting $\mathrm{Mg}-\mathrm{RE}$ alloys with LPSO phases that have been developed in the last 5 years $[32,58,59,68,70,78,81-84,88,100,107,117-119]$. Both the strength (from 150 to $410 \mathrm{MPa}$ ) and ductility (from 1.5 to $13 \%$ ) vary greatly depending on different processing states and alloy compositions. Generally, the as-cast $\mathrm{Mg}-\mathrm{RE}-\mathrm{Zn}$ alloys show relatively low strength and ductility [70, 83, 88]. After T4 treatment, the ductility is improved with elongation of more than $10 \%$, but the improvement in strength is negligible $[32,83,119]$. With a further aging process, the T6 alloys usually exhibit high ultimate tensile strength of over $300 \mathrm{MPa}$. As shown in Fig. 10, the alloys with UTS higher than $300 \mathrm{MPa}$ are all T6-staged alloys, suggesting that precipitates play an important role in strengthening the LPSOcontaining cast alloys $[32,58,59,78,83,100,107,117]$.

The 18R LPSO phases in the as-cast $\mathrm{Mg}-\mathrm{Y}-\mathrm{Zn}$ alloys show a continuous network shape. Microcracks are easily to be formed during tensile at the junctions of networks, thereby impairing both the strength and ductility of as-cast alloys [23]. After T4 treatment, the lamellar-shaped $14 \mathrm{H}$ phases are developed, forming a sandwiched structure with embedded $\alpha-\mathrm{Mg}$ slices. The $14 \mathrm{H}$ lamellar phase exhibits better plasticity than the $18 \mathrm{R}$ phase, and the $14 \mathrm{H} / \alpha-\mathrm{Mg}$ sandwich structure is effective to block dislocations movement within the $\alpha-\mathrm{Mg}$ lamellae [21]. Hence, the T4-treated $\mathrm{Mg}-\mathrm{RE}-\mathrm{Zn}$ alloys with 14H LPSO lamellae display improved ductility, as well as enhanced or nearly unchanged strength. With the further precipitation of nanosized $\beta^{\prime}$ phases during aging, the strength of the alloys increases remarkably. It has already been accepted that the architecture of lamellar LPSO phase and $\beta^{\prime}$ precipitates within $\alpha-\mathrm{Mg}$ grains is effective in strengthening, and the alloys with this novel microstructure are considered to be the next-generation magnesium alloys with high strength and high ductility [2].

Apart from the prismatic $\beta^{\prime}$ precipitates, the basal $\gamma^{\prime \prime}$ or $\gamma^{\prime}$ precipitates also exhibit a great strengthening effect. $\mathrm{Wu}$ et al. [58] introduced $\gamma^{\prime}$ precipitates in aged $\mathrm{Mg}-\mathrm{Gd}-\mathrm{Zn}$ alloy and found that the composite $\beta^{\prime}$ and $\gamma^{\prime}$ precipitates with their relative perpendicular distribution provided a much stronger strengthening effect than the sole $\beta^{\prime}$ precipitates in the $\mathrm{Mg}-\mathrm{Gd}$ alloys. Moreover, the composite $\beta^{\prime}$ and $\gamma^{\prime}$ precipitates effectively strengthened the grain interior and hindered the twining during the tensile tests.

At present, most discussions on the strengthening effect of LPSO phases were focused on wrought alloys. As for the LPSO-containing cast alloys, the intrinsic property of LPSO structure contributes to the improvement in strength. First, the hardness and modulus of LPSO phase are higher than those of $\alpha-\mathrm{Mg}$ matrix [89]. Thus, the LPSO phase could bear more stress during loading. Second, the coherent LPSO/ $\alpha-\mathrm{Mg}$ interface could effectively hinder the movement of dislocations, especially for the $14 \mathrm{H}$ lamellae precipitated within and across the $\alpha-\mathrm{Mg}$ grains [21]. Finally, kinking of LPSO phase formed during tensile could also improve the strength $[52,120]$. As $(0001)\langle 11 \overline{2} 0\rangle$ basal slip is the dominant slip system for LPSO phase, which is often inhibited due to the orientations, kinking become an common plastic mode for LPSO structure and is observed in deformed alloys. The formation of kinking is associated with the arrangement of arrayed dislocations, which could further accommodate a large number of dislocations within [52].

In addition, alloying with other elements such as $\mathrm{Zr}$ and $\mathrm{Ti}$, or with $\mathrm{B}_{4} \mathrm{C}$ and $\mathrm{TiB}_{2}$ particles, is also effective to strengthen the alloy $[82,83,86,87]$. These elements or particles could provide heterogeneous nuclei for $\alpha-\mathrm{Mg}$ or LPSO phases during solidification, resulting in the formation of refined $\alpha-\mathrm{Mg}$ grains or changing the morphology of LPSO phase with dispersed distribution. Consequently, the finegrained strengthening is activated, and the LPSO strengthening effect is also improved.

\subsection{Elevated Temperature Mechanical Properties}

Since LPSO structure is a thermal stable phase with high melting points, they could improve the high-temperature mechanical properties of the $\mathrm{Mg}-\mathrm{RE}$ alloys. By now, only a few works reported the high-temperature tensile or compression properties of these alloys [117]. Yin et al. [117] tested the peak-aged $\mathrm{Mg}-11 \mathrm{Y}-5 \mathrm{Gd}-2 \mathrm{Zn}-0.5 \mathrm{Zr}$ alloy at high temperatures systematically. The strength of this alloy at above $150{ }^{\circ} \mathrm{C}$ was higher than that of the commercial heat-resistant WE54-T6 alloy and several aluminum alloys (A380-T6 and AC8A-T6). Moreover, this alloy even showed the anomalous temperature dependence of strength, with tensile strength at a temperature range of $150-200^{\circ} \mathrm{C}$ higher than that at room temperature. This suggests that the thermal stable LPSO phase greatly improved the high-temperature tensile strength of the alloy.

To evaluate the heat-resistant properties of the LPSOreinforced $\mathrm{Mg}-\mathrm{RE}-\mathrm{Zn}$ cast alloys, creep tests are always performed. Garcés et al. [121] investigated the creep behavior of a typical $\mathrm{Mg}_{97} \mathrm{Y}_{2} \mathrm{Zn}_{1}$ alloy in as-cast state (with 18R LPSO network phase) and thermal treated state (with lamellar $14 \mathrm{H}$ phase inside $\alpha-\mathrm{Mg}$ grains) from 200 to $350{ }^{\circ} \mathrm{C}$. Both alloys exhibited superior creep resistance than conventional commercial magnesium alloys and other Mg-RE-based alloys without LPSO. At low temperatures and/or high strain rates, the alloys showed a high stress exponent of 11 and high activation energy. In this case, the alloy could be regarded as a composite in which the matrix transferred part of its load to the hard LPSO phase, and the heat treated alloy displayed better creep resistance due to the additional barrier induced by the 14H LPSO lamellae. However, at high temperatures and/ or low strain rates, the as-cast alloy showed better creep resistance. In this situation, the creep was controlled by non-basal dislocation slip (with stress exponent of 5). The transformation from $18 \mathrm{R}$ to $14 \mathrm{H}$ occurred for the cast alloy during creep, 
and the diffusion of solute atoms inhibited the movement of dislocations. Srinivasan et al. [122] recently studied the creep behavior of two $\mathrm{Mg}-10 \mathrm{Gd}-x \mathrm{Zn}(x=2$ and 6) alloys. Similarly, the LPSO-containing alloys exhibited better creep resistance than other alloy series. High stress exponent values (6.8-8.8) were obtained for the two alloys, and they considered pipe diffusion and diffusion of $\mathrm{Gd}$ as the rate controlling creep mechanism at both 250 and $300{ }^{\circ} \mathrm{C}$. From the above descriptions, it can be concluded that both $18 \mathrm{R}$ and $14 \mathrm{H}$ LPSO phases could improve the creep resistance of the $\mathrm{Mg}-\mathrm{Y}-\mathrm{Zn}$ alloys, but the role of these two phases during creep was different.

Once again, the unique microstructure of peak-aged alloys with LPSO lamellae and $\beta^{\prime}$ precipitates perpendicular to each other elicited an excellent strengthening effect at elevate temperatures $[2,123,124]$. Due to the good thermal stability, the LPSO phase in Mg-RE- $X$ alloys can retard grain growth and inhibit the coarsening of predominant strengthening $\beta^{\prime}$ phase at elevated temperatures. As the sizes of $\beta^{\prime}$ phases remain unchanged by hindering the LPSO lamellae, the strengthening effect of $\beta^{\prime}$ precipitates on $\alpha-\mathrm{Mg}$ grains is still at play at high temperatures for longterm exposure. By characterizing the microstructures of a Mg-12Gd-3Y-1Zn-0.4Zr T6 alloy before and after creep tests, Zhu et al. [123] confirmed that the $\beta^{\prime}$ precipitates did not change after creep at $250{ }^{\circ} \mathrm{C}$ for $100 \mathrm{~h}$, but they transformed to $\beta$ phases and their sizes grew from nanosize to several micrometers when crept at $280{ }^{\circ} \mathrm{C}$. The size of $\beta$ phases grew coarser with further increasing the creep temperature. The formation and growth of $\beta$ phase plates were responsible for the softening of material during creep.

\section{Conclusions and Future Perspectives}

We provide a brief review on the recent development of Mg-RE-TM cast alloys with long period stacking ordered phases. Much attention has been placed on the beneficial effect of alloying elements on the morphology of LPSO phases, the transformation mechanism of LPSO structures during heat treatment, the impact of different casting techniques on microstructures, the precipitation behaviors of various precipitates and their interaction with LPSO phases, as well as the influence of the above microstructure evolutions on the mechanical properties of the LPSO-containing cast alloys. Based on the above referred researches, we have drawn several conclusions and presented some topics that are worth further investigations in the future for the development of high-performance $\mathrm{Mg}-\mathrm{RE}-\mathrm{TM}$ cast alloys.

(1) Alloying with minor $\mathrm{Zr}, \mathrm{Sr}, \mathrm{Ca}, \mathrm{B}, \mathrm{Ti}, \mathrm{Sn}$ and Mn elements could refine the microstructures, promote the disperse distribution of LPSO phases and enhance the strength of the cast alloys via fine-grained strengthening and effective LPSO strengthening. Moreover, microalloying with $\mathrm{Sr}, \mathrm{Ca}$ and $\mathrm{B}$ elements promotes the formation of LPSO phases and remarkably increases the volume fraction of LPSO phase in alloys even with lower RE contents. Therefore, it is feasible to develop low-RE alloyed high-strength Mg-RE-TM alloys with higher LPSO contents and lower cost by adding proper alloying elements. Furthermore, developing an RE-free LPSO-containing magnesium alloy is challenging, but is equally rewarding.

(2) The thermal activated transformation of $14 \mathrm{H} \mathrm{LPSO}$ structure could be proceeded by two ways: direct transformation form 18R structure with the assistance of two Shockley partials gliding or precipitation from the supersaturated $\alpha$-Mg grains on the basal $\gamma^{\prime}$ precipitates. Future studies are needed to elucidate which transformation mechanism plays a dominant role in a certain situation, especially for the Mg-Y-Zn type-I alloys in which these two mechanisms could be both at play. In addition, other LPSO structures, such as $12 \mathrm{H}$ and 24R, were also reported in the Mg-RE-TM alloys. Detailed investigations on the structure and transformation mechanism are necessary, which could reveal the possibility of stable and abundant existence of these LPSO structures independently, as well as their impact on the mechanical properties of the alloys.

(3) Special casting (such as rapid solidification and directional solidification) of the LPSO-containing alloys could introduce unique microstructures, such as nanocrystalline, nanosized LPSO particles and supersaturated solid solution, which impart the alloys with higher strength compared with alloys prepared by conventional casting. With proper heat treatments, the conventional casting alloys could obtain high comprehensive mechanical properties with ultimate tensile strength of over $400 \mathrm{MPa}$ and elongation of above $5 \%$, which mainly resulted from the interaction of LPSO phases and nanoprecipitates. Two precipitation sequences, $\beta$ and $\gamma$ series, were reported and established in these alloys. Future research should place emphasis on the thermodynamics and kinetics of these two precipitates, as well as their competing or synergetic precipitation mechanisms, in order to accomplish the controllable preparation of high-performance alloys with ideal microstructures.

(4) The potential beneficial effects of adding ceramic particles in the LPSO-containing alloys have already been confirmed recently. There is an increasing trend to fabricate high-strength $\mathrm{Mg}$ alloys via the compound strengthening effect. Therefore, the strengthening strategy combining fine-grained strengthening, LPSO strengthening, precipitation strengthening, solid solu- 
tion strengthening and even with reinforced ceramic particles should be adopted. The convenient processing methods, which could be easily employed in industry applications, should also be developed.

(5) The performance of these alloys under practical application environments is rarely studied. To further broaden the applications of the LPSO-containing alloys, more researches on the corrosion, creep, impact, wear and fatigue properties of the alloys should be performed in the future.

Acknowledgements The authors thank for the supports of the Natural Science Foundation of Jiangsu Province of China (No. BK20160869), the Fundamental Research Funds for the Central Universities (No. 2018B16614) and the National Natural Science Foundation of China (No. 51774109).

\section{References}

[1] J.H. Zhang, S.J. Liu, R.Z. Wu, L.G. Hou, M.L. Zhang, J. Magnes. Alloys 6, 277 (2018)

[2] Y.S. Li, C.L. Yang, X.Q. Zeng, P.P. Jin, D. Qiu, W.J. Ding, Mater. Charact. 141, 286 (2018)

[3] Z. Luo, S. Zhang, J. Mater. Sci. Lett. 19, 813 (2000)

[4] Z. Luo, S. Zhang, Y. Tang, D. Zhao, J. Alloys Compd. 209, 275 (1994)

[5] Y. Kawamura, K. Hayashi, A. Inoue, T. Masumoto, Mater. Trans. 42, $1172(2001)$

[6] Y. Kawamura, M. Yamasaki, Mater. Trans. 48, 2986 (2007)

[7] S.Q. Yin, Z.Q. Zhang, X. Liu, Q.C. Le, Q. Lan, L. Bao, J.Z. Cui, Mater. Sci. Eng. A 695, 135 (2017)

[8] Y. Kawamura, T. Kasahara, S. Izumi, M. Yamasaki, Sci. Mater. $\mathbf{5 5}, 453$ (2006)

[9] H. Liu, F. Xue, J. Bai, J. Zhou, J. Mater. Eng. Perform. 22, 3500 (2013)

[10] H. Liu, F. Xue, J. Bai, J. Zhou, X.D. Liu, Mater. Sci. Eng. A 585, 387 (2013)

[11] W. Liu, J.S. Zhang, C.X. Xu, X.M. Zong, W. Zhu, Q.Q. Ma, J. Mater. Sci. 22, 13271 (2017)

[12] J. Yin, C.H. Lu, X.J. Ma, B.Y. Dai, H.L. Chen, Intermetallics 68, $63(2016)$

[13] Z.Z. Peng, X.H. Shao, Q.Q. Jin, C.H. Li, X.L. Ma, Scr. Mater. 116, 57 (2016)

[14] K. Kishida, H. Yokobayashi, H. Inui, M. Yamasaki, Y. Kawamura, Intermetallics 31, 55 (2012)

[15] D.K. Xu, E.H. Han, Y.B. Xu, Prog. Nat. Sci. Mater. 26, 117 (2016)

[16] M. Matsuda, S. Ii, Y. Kawamura, Y. Ikuhara, M. Nishida, Mater. Sci. Eng. A 393, 269 (2005)

[17] K. Hagihara, T. Okamoto, H. Izuno, M. Yamasaki, M. Matsushita, T. Nakano, Y. Kawamura, Acta Mater. 109, 90 (2016)

[18] Y.M. Zhu, A.J. Morton, J.F. Nie, Acta Mater. 60, 6562 (2012)

[19] C. Liu, Y.M. Zhu, Q. Luo, B. Liu, Q.F. Gu, Q. Li, J. Mater. Sci. Technol. 34, 2235 (2018)

[20] J.F. Nie, Y.M. Zhu, A.J. Morton, Metall. Mater. Trans. A 45, 3338 (2014)

[21] H. Liu, F. Xue, J. Bai, Y.S. Sun, Mater. Sci. Eng. A 585, 261 (2013)

[22] X.J. Wang, D.K. Xu, R.Z. Wu, X.B. Chen, Q.M. Peng, L. Jin, Y.C. Xin, Z.Q. Zhang, Y. Liu, X.H. Chen, G. Chen, K.K. Deng, H.Y. Wang, J. Mater. Sci. Technol. 34, 245 (2018)
[23] H. Liu, F. Xue, J. Bai, J. Zhou, Y.S. Sun, Rare Met. Mater. Eng. 24, 570 (2014)

[24] J.F. Wang, P.F. Song, S. Gao, Y.Y. Wei, F.S. Pan, J. Mater. Sci. 47, 2005 (2012)

[25] J. Gröbner, A. Kozlov, X.Y. Fang, J. Geng, J.F. Nie, R. SchmidFetzer, Acta Mater. 60, 5948 (2012)

[26] N. Tahreen, D.F. Zhang, F.S. Pan, X.Q. Jiang, D.Y. Li, D.L. Chen, J. Mater. Sci. Technol. 34, 1110 (2018)

[27] Y.L. Chen, L. Jin, J. Dong, F.H. Wang, Y.X. Li, Y.L. Li, H.C. Pan, X. Nie, Mater. Charact. 134, 253 (2017)

[28] Y. Li, W.L. Xiao, F. Wang, T. Hu, C.L. Ma, J. Alloys Compd. 745, 33 (2018)

[29] C. Xu, G.H. Fan, T. Nakata, X. Liang, Y.Q. Chi, X.G. Qiao, G.J. Cao, T.T. Zhang, M. Huang, K.S. Miao, M.Y. Zheng, S. Kamado, H.L. Xie, Metall. Mater. Trans. A 49, 1931 (2018)

[30] Z.J. Yu, C. Xu, J. Meng, X.H. Zhang, S. Kamado, J. Alloys Compd. 729, 627 (2017)

[31] X.J. Zhou, C.M. Liu, Y.H. Gao, S.N. Jiang, X.Z. Han, Z.Y. Chen, Metall. Mater. Trans. A 48, 3060 (2017)

[32] K. Wen, W.B. Du, K. Liu, Z.H. Wang, S.B. Li, Rare Met. 35, 443 (2016)

[33] K. Wen, W.B. Du, K. Liu, Z.H. Wang, S.B. Li, Rare Met. 35, 367 (2016)

[34] J.H. Zhang, Z. Leng, S.J. Liu, J.Q. Li, M.L. Zhang, R.Z. Wu, J. Alloys Compd. 509, 7717 (2011)

[35] L. Zhang, J.H. Zhang, Z. Leng, S.J. Liu, Q. Yang, R.Z. Wu, M.L. Zhang, Mater. Des. 54, 256 (2014)

[36] Z.J. Yu, Y.D. Huang, W.M. Gan, C.L. Mendis, Z.Y. Zhong, H.G. Brokmeier, N. Hort, J. Meng, Mater. Sci. Eng. A 657, 259 (2016)

[37] H. Liu, J. Ju, X.W. Yang, J.L. Yan, D. Song, J.H. Jiang, A.B. Ma, J. Alloys Compd. 704, 509 (2017)

[38] H. Liu, J. Ju, F.M. Lu, J.L. Yan, J. Bai, J.H. Jiang, A.B. Ma, Mater. Sci. Eng. A 682, 255 (2017)

[39] J. Zhu, X.H. Chen, L. Wang, W.Y. Wang, Z.K. Liu, J.X. Liu, X.D. Hui, J. Alloys Compd. 703, 508 (2017)

[40] E. Abe, Y. Kawamura, K. Hayashi, A. Inoue, Acta Mater. 50, $3845(2002)$

[41] G. Garcés, G. Requena, D. Tolnai, P. Pérez, J. Medina, A. Stark, N. Schell, P. Adeva, Mater. Charact. 118, 514 (2016)

[42] K. Liu, W.B. Du, S.B. Li, Z.H. Wang, J. Magnes. Alloys 4, 99 (2016)

[43] P. Pérez, G. Garcés, M. Maeso, P. Adeva, Metall. Mater. Trans. A 43, 4383 (2012)

[44] B.S. Wang, Y.B. Liu, J. An, R.G. Li, Z.G. Su, G.H. Su, Y. Lu, Z.Y. Cao, Mater. Trans. 49, 1768 (2008)

[45] B.S. Wang, Y.B. Liu, J. An, R.G. Li, Z.G. Su, Z.Y. Cao, Trans. Nonferrous Metal. Soc. 18, s69 (2008)

[46] K. Hagihara, Z.X. Li, M. Yamasaki, Y. Kawamura, T. Nakano, Mater. Lett. 214, 119 (2018)

[47] M. Yamasaki, M. Matsushita, K. Hagihara, H. Izuno, E. Abe, Y. Kawamura, Scr. Mater. 78-79, 13 (2014)

[48] M. Tane, Y. Nagai, H. Kimizuka, K. Hagihara, Y. Kawamura, Acta Mater. 61, 6338 (2013)

[49] K. Hagihara, M. Honnami, R. Matsumoto, Y. Fukusumi, H. Izuno, M. Yamasaki, T. Okamoto, T. Nakano, Y. Kawamura, Mater. Trans. 56, 943 (2015)

[50] K. Hagihara, Y. Fukusumi, M. Yamasaki, T. Nakano, Y. Kawamura, Mater. Trans. 54, 693 (2013)

[51] K. Hagihara, Y. Sugino, Y. Fukusumi, Y. Umakoshi, T. Nakano, Mater. Trans. 52, 1096 (2011)

[52] K. Hagihara, N. Yokotani, Y. Umakoshi, Intermetallics 18, 267 (2010)

[53] Z.C. Xu, Z.X. Feng, Q.N. Shi, Y.X. Yang, X.Q. Wang, H.R. Qi, Mater. Rev. 32, 865 (2018) 
[54] J.W. Dai, X.B. Zhang, Y. Fei, Z.Z. Wang, H.M. Sui, Acta Metall. Sin. (Engl. Lett.) 31, 865 (2018)

[55] L.T. Yuan, G.L. Bi, Y.D. Li, J. Jiang, Y.X. Han, D.Q. Fang, Y. Ma, Trans. Nonferrous Metal. Soc. 27, 2381 (2017)

[56] M. Li, X. Wang, Q.Y. Feng, J. Wang, Z. Xu, P.H. Zhang, Mater. Charact. 125, 123 (2017)

[57] J.F. Wang, P.F. Song, S. Huang, F.S. Pan, Mater. Sci. Eng. A $\mathbf{5 6 3}, 36$ (2013)

[58] W. Rong, Y.J. Wu, Y. Zhang, M. Sun, J. Chen, L.M. Peng, W.J. Ding, Mater. Charact. 126, 1 (2017)

[59] J.C. Li, Z.L. He, P.H. Fu, Y.J. Wu, L.M. Peng, W.J. Ding, Mater. Sci. Eng. A 651, 745 (2016)

[60] G.D. Zou, X.C. Cai, D.Q. Fang, Z. Wang, T.S. Zhao, Q.M. Peng, Mater. Sci. Eng. A 620, 10 (2015)

[61] H. Liu, H. Huang, X.W. Yang, C. Li, J.L. Yan, J.H. Jiang, A.B. Ma, J. Magnes. Alloys 5, 231 (2017)

[62] H. Liu, Z.J. Cheng, K. Yan, J.L. Yan, J. Bai, J.H. Jiang, A.B. Ma, J. Mater. Sci. Technol. 32, 1274 (2016)

[63] W.T. Sun, C. Xu, X.G. Qiao, M.Y. Zheng, S. Kamado, N. Gao, M.J. Starink, Mater. Sci. Eng. A 700, 312 (2017)

[64] R. Lapovok, X. Gao, J.F. Nie, Y. Estrin, S.N. Mathaudhu, Mater. Sci. Eng. A 615, 198 (2014)

[65] X.W. Li, F.Y. Zheng, Y.J. Wu, L.M. Peng, Y. Zhang, D.L. Lin, W.J. Ding, Mater. Lett. 113, 206 (2013)

[66] Q. Yang, B.L. Xiao, D. Wang, M.Y. Zheng, K. Wu, Z.Y. Ma, J. Alloys Compd. 581, 585 (2013)

[67] F.S. Pan, M.B. Yang, X.H. Chen, J. Mater. Sci. Technol. 32, $1211(2016)$

[68] K. Yang, J.S. Zhang, X.M. Zong, W.X. Wang, C.X. Xu, W.L. Cheng, K.B. Nie, Mater. Sci. Eng. A 669, 340 (2016)

[69] S.Q. Luo, A.T. Tang, F.S. Pan, K. Song, W.Q. Wang, Trans. Nonferrous Metal. Soc. 21, 795 (2011)

[70] C.Q. Li, D.K. Xu, Z.R. Zeng, B.J. Wang, L.Y. Sheng, X.B. Chen, E.H. Han, Mater. Des. 121, 430 (2017)

[71] E. Oñorbe, G. Garcés, P. Pérez, P. Adeva, J. Mater. Sci. 47, 1085 (2012)

[72] B. Chen, D.L. Lin, X.Q. Zeng, C. Lu, J. Mater. Sci. 45, 2510 (2010)

[73] Y.J. Wu, D.L. Lin, X.Q. Zeng, L.M. Peng, W.J. Ding, J. Mater. Sci. 44, 1607 (2009)

[74] Y.M. Zhu, A.J. Morton, J.F. Nie, Acta Mater. 58, 2936 (2010)

[75] Y.X. Du, Y.J. Wu, L.M. Peng, J. Chen, X.Q. Zeng, W.J. Ding, Mater. Lett. 169, 168 (2016)

[76] M. Yamasaki, K. Hashimoto, K. Hagihara, Y. Kawamura, Acta Mater. 59, 3646 (2011)

[77] S. Zhang, G.Y. Yuan, C. Lu, W.J. Ding, J. Alloys Compd. 509, 3515 (2011)

[78] J.S. Zhang, W.B. Zhang, X.Q. Ruan, L.P. Bian, W.L. Cheng, H.X. Wang, C.X. Xu, Mater. Sci. Eng. A 560, 847 (2013)

[79] J.S. Zhang, C. Xin, W.L. Cheng, L.P. Bian, H.X. Wang, C.X. Xu, J. Alloys Compd. 558, 195 (2013)

[80] J.S. Zhang, C.J. Chen, Z.P. Que, W.L. Cheng, J.D. Xu, J.J. Kang, Mater. Sci. Eng. A 552, 81 (2012)

[81] J. Wang, J.S. Zhang, X.M. Zong, C.X. Xu, Z.Y. You, K.B. Nie, Mater. Sci. Eng. A 648, 37 (2015)

[82] X. Zhao, L.L. Shi, J. Xu, J. Mech. Behav. Biomed. 18, 181 (2013)

[83] P. Cheng, Y.H. Zhao, R.P. Lu, H. Hou, Z.Q. Bu, F. Yan, Mater. Sci. Eng. A 708, 482 (2017)

[84] J.J. Gao, Y.A. Chen, Y. Wang, Mater. Sci. Eng. A 711, 334 (2018)

[85] D. Li, J.S. Zhang, Z.P. Que, C.X. Xu, X.F. Niu, Mater. Lett. 109, $46(2013)$

[86] Y. Li, Z. Zhang, J.S. Zhang, Y.B. Ma, Y.T. Zhang, C.X. Xu, Adv. Eng. Mater. 20, 1800131 (2018)

[87] Y.B. Ma, J.S. Zhang, C.X. Xu, Y. Li, Y.T. Zhang, Z. Zhang, Mater. Sci. Eng. A 724, 529 (2018)
[88] J.H. Zhang, L.J. Xu, Y.F. Jiao, C. Xu, L. Zhang, S.J. Liu, J. Meng, R.Z. Wu, M.L. Zhang, Mater. Sci. Eng. A 610, 139 (2014)

[89] T. Itoi, T. Seimiya, Y. Kawamura, M. Hirohashi, Scr. Mater. 51, 107 (2004)

[90] M. Yamasaki, M. Sasaki, M. Nishijima, K. Hiraga, Y. Kawamura, Acta Mater. 55, 6798 (2007)

[91] H. Liu, J. Bai, K. Yan, J.L. Yan, A.B. Ma, J.H. Jiang, Mater. Des. 93, 9 (2016)

[92] D.J. Li, X.Q. Zeng, J. Dong, C.Q. Zhai, Trans. Nonferrous Metal. Soc. 18, s117 (2008)

[93] H. Liu, F. Xue, J. Bai, A.B. Ma, J.H. Jiang, J. Mater. Sci. Technol. 32, 1267 (2016)

[94] X.Y. Tan, K.H.W. Chee, K.W.J. Chan, K.W.O. Richard, G. Manoj, Mater. Sci. Eng. A 644, 405 (2015)

[95] H. Liu, K. Yan, J.L. Yan, F. Xue, J.P. Sun, J.H. Jiang, A.B. Ma, Trans. Nonferrous Metal. Soc. 27, 63 (2017)

[96] Y.M. Zhu, M. Weyland, A.J. Morton, K. Oh-ishi, K. Hono, J.F. Nie, Scr. Mater. 60, 980 (2009)

[97] J.F. Nie, K. Oh-ishi, X. Gao, K. Hono, Acta Mater. 56, 6061 (2008)

[98] Y.M. Zhu, A.J. Morton, M. Weyland, J.F. Nie, Acta Mater. 58, $464(2010)$

[99] D.D. Yin, Q.D. Wang, Y. Gao, C.J. Chen, J. Zheng, J. Alloys Compd. 509, 1696 (2011)

[100] S. Zhang, W.C. Liu, X.Y. Gu, C. Lu, G.Y. Yuan, W.J. Ding, J. Alloys Compd. 557, 91 (2013)

[101] Y.X. Li, D. Qiu, Y.H. Rong, M.X. Zhang, Intermetallics 40, 45 (2013)

[102] M. Nishijima, K. Hiraga, Mater. Trans. 48, 10 (2007)

[103] M. Nishijima, K. Yubuta, K. Hiraga, Mater. Trans. 48, 84 (2007)

[104] K. Saito, K. Hiraga, Mater. Trans. 52, 1860 (2011)

[105] A. Issa, J.E. Saal, C. Wolverton, Acta Mater. 83, 75 (2015)

[106] J.F. Nie, N.C. Wilson, Y.M. Zhu, Z. Xu, Acta Mater. 106, 260 (2016)

[107] W. Fu, R.H. Wang, H. Xue, J. Kuang, J.Y. Zhang, G. Liu, J. Sun, J. Alloys Compd. 747, 197 (2018)

[108] Z. Xu, M. Weyland, J.F. Nie, Acta Mater. 81, 58 (2014)

[109] X.F. Gu, T. Furuhara, T. Kiguchi, T.J. Konno, L. Chen, P. Yang, Scr. Mater. 146, 64 (2018)

[110] Z. Li, J. Zheng, B. Chen, Mater. Charact. 120, 345 (2016)

[111] Y.M. Zhu, K. Oh-ishi, N.C. Wilson, K. Hono, A.J. Morton, J.F. Nie, Metall. Mater. Trans. A 47, 927 (2016)

[112] M. Nishijima, K. Hiraga, M. Yamasaki, Y. Kawamura, Mater. Trans. 49, 227 (2008)

[113] J.X. Zheng, B. Chen, Mater. Lett. 176, 223 (2016)

[114] K. Hagihara, A. Kinoshita, Y. Sugino, M. Yamasaki, Y. Kawamura, H.Y. Yasuda, Y. Umakoshi, Intermetallics 18, 1079 (2010)

[115] K. Hagihara, A. Kinoshita, Y. Sugino, M. Yamasaki, Y. Kawamura, H.Y. Yasuda, Y. Umakoshi, Acta Mater. 58, 6282 (2010)

[116] X. Yang, S.S. Wu, S.L. Lü, L.Y. Hao, X.G. Fang, Ultrason. Sonochem. 40, 472 (2018)

[117] J.W. Lu, D.D. Yin, L.B. Ren, G.F. Quan, J. Mater. Sci. 51, 10464 (2016)

[118] D.D. Wang, W.B. Zhang, X.M. Zong, K.B. Nie, C.X. Xu, J.S Zhang, Mater. Sci. Eng. A 618, 355 (2014)

[119] M. Li, K. Zhang, X.G. Li, Y.J. Li, M.L. Ma, G.L. Shi, J.W. Yuan, T. Li, J.B. Liu, Mater. Sci. Eng. A 626, 415 (2015)

[120] X.H. Shao, Z.Q. Yang, X.L. Ma, Acta Mater. 58, 4760 (2010)

[121] G. Garcés, E. Oñorbe, F. Dobes, P. Pérez, J.M. Antoranz, P. Adeva, Mater. Sci. Eng. A 539, 48 (2012)

[122] A. Srinivasan, H. Dieringa, C.L. Mendis, Y. Huang, R. Rajesh Kumar, K.U. Kainer, N. Hort, Mater. Sci. Eng. A 649, 158 (2016)

[123] X.R. Zhu, J. Wang, Y.D. Xu, R. Wang, J.J. Nie, L.P. Zhu, J. Rare Earth 31, 186 (2013)

[124] H. Liu, F. Xue, J. Bai, J. Zhou, Y.S. Sun, J. Mater. Sci. Technol. 30, 128 (2014) 


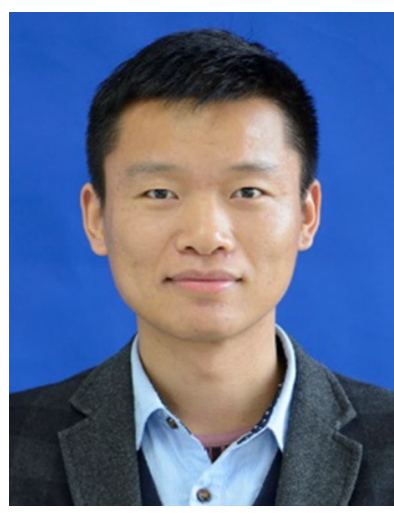

Huan Liu is a Lecturer, Master's Supervisor, College of Mechanics and Materials, Hohai University. He earned his Ph.D. from Southeast University in 2014 and then became a Lecturer in Hohai University. He was selected into the "Shuangchuang Program of Jiangsu Province" and "Dayu Scholars Program of Hohai University" in 2017. So far, he has published more than 30 scientific papers (indexed by SCI) and held 2 authorized Chinese patents. His papers were cited more than 200 times. His research interests mainly include design of high-strength and high ductility magnesium alloys, heat-resistant magnesium alloys, fabrication of fine-grained and ultra-fine-grained metallic materials, and biomedical materials.

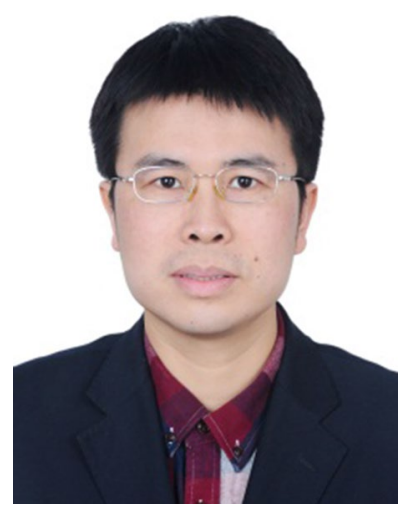

Xian-Hua Chen is a Professor of Chongqing University and received his Doctor's degree from Institute of Metal Research, Chinese Academy of Sciences in 2008. He is Director of Institute of Functional Mg Alloys in National Engineering Research Centre for Magnesium Alloys, Director of International Joint Laboratory for Light Alloys (Ministry of Education), Editorial Board of Acta Metallurgica Sinica (English Letters) (SCI). His research work is focused on new high-performance structural and functional magnesium alloys, and purification technology of magnesium alloys. He also worked in Materials Technology Laboratory of CANMET in Canada as visiting scientist during 2012-2013. He has 22 patents, 1 book and more than 60 SCI papers, including 2 science papers. His papers were cited more than 2700 times. He was awarded the Provincial and Ministerial S\&T Prize in 2013, 2014 and 2017. He was the Chairman of "The 2nd China Youth Scholars Conference on Mg Alloys." 